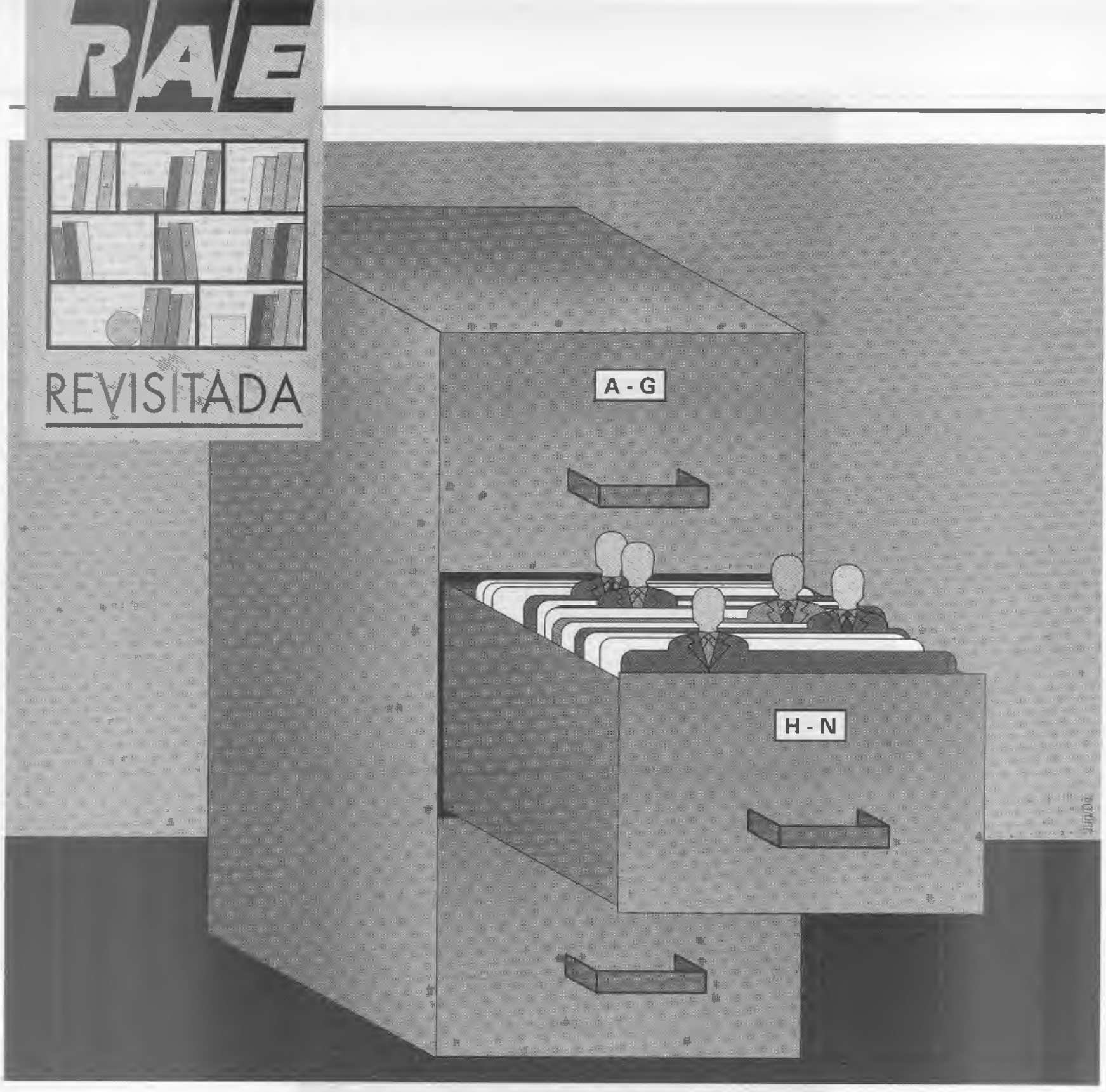

\title{
CONTROLE SOCIAL NAS ORGANIZAÇÕES
}

- Fernando C. Prestes Motta

Professor do Departamento de Administração Geral e Recursos Humanos da EAESP/FGV

Revisitado por Isabella F. F. Gouyeia de Vasconcelos e Thomaz Wood Jr., Doutorandos na EAESP/FGV.

* RESUMO: O presente trabalho apresenta vários aspectos do controle social nas organizações $e$ analisa as contribuiçôes de Merton, Selznick, Goudner, Crozier, o grupo de Aston e Weber. Foi originariamente publicado por Motta em 1979, e é revisitado por Vasconcelos e Wood Jr., que atualizam a bibliografia e adicionam alguns comentários, acrescentando a perspectiva simbólica aos argumentos originais. Esta nova perspectiva foi esboçada pelo próprio autor original, no curso "Simbolismo Organizacional", realizado na EAESP/FGV (1ํ) semestre, 1993).
* PALAVRAS-CHAVE: Controle social, organizações, simbolismo, burocracia, socialização.

* ABSTRACT: This article presents several aspects of social control at organizations and analyses the points of view of Merton, Selznick, Gouldner, Crozier the Aston Group and Weber. It was originally published in 1979 by Professor Motta and it is now revisited by Vasconcelos and Wood Jr., who updated the bibliography and added some commentaries in order to stress the symbolic perspective in the arguments originally presented. This new perspective was ouflined by the author - in his own course "Organizational Symbolism" at EAESP-FGV (1 st semester 1993).

* KEY WORDS: Social control, organizations, symbolism, bureaucracy, socialization. 


\section{APRESENTAÇÃO}

A temática do controle social nas organizações é central na análise organizacional por diversas razões, entre as quais se destaca o fato de que as organizações são essencialmente instâncias de produção de bens, de conhecimentos etc., bem como instâncias de controle, a serviço de sistemas sociais maiores. Tal fato não tem passado despercebido à teoria organizacional, tanto no que diz respeito aos mecanismos de controle que se efetivam no interior das organizações, como no que se refere à crítica, já dotada de ampla tradição na área, e às formas tradicionais assumidas pelos arranjos organizacionais altamente voltados para a função de controle social. A proposta original contida neste ensaio foi colocar o problema do controle social nas organizações e esboçar uma avaliação da Literatura Clássica corrente, na crítica dos arranjos organizacionais altamente voltados para a função do controle social. Isto posto, haverá possibilidade de formulação de uma hipótese maior, dedutível em outras, tanto no que diz respeito à pesquisa teórica quanto à empírica.

Desde a publicação original do artigo, em 1979, houve algumas mudanças nas formas de controle social exercidas pelas organizações. Com o delineamento da chamada sociedade pós-industrial, caracterizada pela rápida criação de novas tecnologias e produtos, as organizações modificam-se; conceitos e papéis organizacionais são redefinidos.

Com a pressão constante para a inovação enquanto estratégia de sobrevivência, surge o conceito da organização pró-ativa; ou seja, aquela organização que não apenas reage às mudanças nos mercados em que atua, mas que pretende influenciá-las. É esta a racionalidade econômica que embasa atualmente o planejamento empresarial. As organizações que seguem esta lógica, também denominadas empresas informacionais ${ }^{1}$, geram uma pressão interna por mudança muito forte. Neste contexto é significativa a figura do "gerente pró-ativo", aquele que consegue antecipar e administrar o impacto das mudanças ambientais sobre as pessoas e sobre a estrutura organizacional, reinterpretando continuamente a realidade que o cerca e difundindo estes novos valores e significados na organização.

A constante socialização e re-socialização dos empregados dentro da empresa, a fim de fazê-los internalizar esta nova "visão de mundo" e estes novos elementos culturais (valores e significados) é um constante desafio, uma vez que permite à organização influenciar os comportamentos dos seus membros e controlar suas performances. Portanto, a tarefa de sociali-

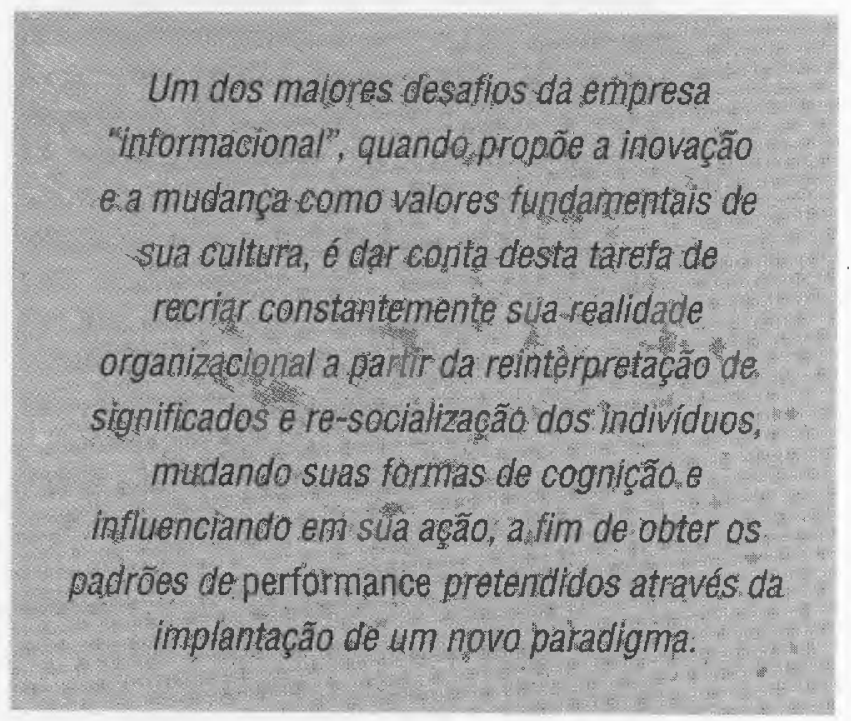

zação, em um contexto de mudança constante, ganha importância estratégica para a organização.

A empresa informacional deve saber processar e lidar com a informação, o que nos remete à questão da linguagem e ao uso de signos e símbolos. Surge o simbolic manager ${ }^{2}$, que utiliza símbolos, rituais, linguagem e outros elementos da cultura organizacional como forma de controle social na empresa.

\section{A organização como sistema de controle social}

Neste sentido, pode-se retomar a linha de argumentação do artigo original, que descreve o processo de socialização do indivíduo na organização.

De início, parece importante colocar o fato de que a organização é o sistema social mais formalizado da sociedade, sendo, portanto, um sistema de significativas condutas institucionalizadas. As organizações, de há muito, são as principais responsáveis pelas formas de conduta dos atores sociais. As empresas são
1. BELL, Daniel. Vers la Société Post industrielle. Paris: R.Laffont,1976; ALTER, Norbert. Logiques de l'entreprise Informationnelle. Revue Française de Gestion, $\pi .74,1989$, р. 28 : MINTZBERG, Henry. Structure et dynamique des Organisations. Paris, Editions des Organisations, 1982

2. DEAL,T.; KENNEDY, A. COrporate Cultures:Rites and Rituals of Corporate Life. New York: Addison-Wesley, 1991. 
3. STINCHOMBE, Arthur. Socia Structure and Organizations. In MARCH, James. Handbook of Organizations. Chicago: Rand McNally, p.144, 1965.

4.ALTER, Norbert. Op. cit. p.30.

5. SMIRCICH, Linda. Organizations as Shared Meanings. In: PONDY, L. (org.) Organisational Symbolism, Greenwich:JAI, 1983, p.55-65.

6. GIOIA D. A.; CHITTIPEDDI, K Sensemaking and sensegiving in strategic change iniciation. Strategic Management Journal, Chichester, v. 12, n. 6 , Sept.1991, p. 20-5.

7. SMIRCICH, Linda. Studing Organizations as Cultures. In:MORGAN,G. (org.) Beyond method: strategies for social research. Bervely Hills: CA, Sage, 1983.

8. CHANLAT, J.F. O indivíduo na organização - dimensões esquecidas. São Paulo: Atlas, 1992. centrais, não só porque produzem bens e serviços, mas também porque produzem formas de comportamento e formas de raciocínio. As escolas, cada vez mais cedo, preparam os indivíduos para determinados papéis no sistema produtivo, com tendência a legitimar as organizações de forma habitual.

As elites organizacionais, por sua vez, têm nesses mecanismos a sua própria lógica. Velhas e novas gerações de elites podem adotar novas atitudes quanto a práticas políticas, administrativas etc. Agem, porém, segundo a lógica da organização, enquanto instância de produção e controle social. Nas palavras de Stinchombe, feitos os reparos de detalhe e de situação específica, “... se as novas elites organizacionais são socializadas em uma cultura de elite, freqüentando escolas com outros membros de elite, participando de parlamentos e sendo ideologicamente doutrinadas em um partido político dominante, estão propensas a aceitar as normas usuais que governam a competição pela riquezas, prestígio $e$ poder organizacionais". ${ }^{3}$

A empresa informacional, como diz Alter ${ }^{4}$,tendo em vista suas pressões constantes por inovação e lidando em um ambiente cheio de incertezas, procura a coesão mais que a coerência interna. Elas tendem a substituir, então, a definição estrita e coercitiva dos modos de produção por uma nova forma de controle social, realizada através da cultura organizacional, composta de determinados valores e significados representativos da visão de mundo das elites e dirigentes empresariais. Um dos maiores desafios da empresa "informacional", quando propõe a inovação e a mudança como valores fundamentais de sua cultura, é dar conta desta tarefa de recriar constantemente sua realidade organizacional a partir da reinterpretação de significados e re-socialização dos indivíduos, mudando suas formas de cognição e influenciando em sua ação, a fim de obter os padrões de performance pretendidos através da implantação de um novo paradigma. ${ }^{5}$

Paradigmas $^{6}$ neste sentido, são mecanismos cognitivos, um conjunto de pressupostos e crenças intimamente ligados à realidade organizacional e normalmente aceitos na organização na forma de significados compartilhados. São filtros da realidade que influenciam na percepção dos indivíduos. Neste contexto, a mudança organizacional é definida como o esforço para alterar as formas vigentes de cognição e ação, de maneira a capacitar a organização a implementar as estratégias por ela desenvolvidas.

A capacidade do indivíduo em influenciar na mudança organizacional está intimamente ligada com a sua posição e o seu poder na empresa. Existem algumas metodologias de pesquisa próprias para o estudo dos símbolos e da cultura enquanto formas de controle social na organização. ${ }^{7}$ Tais estudos mostram como é difícil o processo de adaptação do indivíduo a uma organização que tenta moldálo mudando suas formas de cognição.

Como ressaltado no artigo original, indivíduos e organização se confrontam com uma série de expectativas mútuas. À medida que tais expectativas jamais são completas e formalmente definidas, há sempre lugar para a surpresa e para a contestação de percepções anteriores. Assim, tanto frustrações como estímulos entram no processo de adaptação indivíduo-organização. Esse processo é sempre bidirecional, com a renúncia de ampla margem de liberdade por parte do indivíduo, que concorda de maneira implícita com as demandas "legítimas" da organização, as quais lhe tolhem a liberdade, limitando seus comportamentos alternativos. A organização amolda, em níveis diversos, o indivíduo às suas necessidades. É o processo de socialização.

Chanlat ${ }^{8}$, em uma de suas últimas publicações, denuncia alguns dos efeitos destas práticas sobre os indivíduos. As organizações, ao fundar-se neste tipo de racionalidade econômica, consideram e privilegiam apenas as características individuais que possam ser úteis para a empresa no processo produtivo.

Já de acordo com os interacionistas, esta mesma organização é criada a partir da ação dos indivíduos. Assim, a realidade organizacional consiste em padrões de significados criados e sustentados pelos indivíduos, construídos a partir de interações simbólicas. Ao entrar em contato com a cultura organizacional, o indivíduo internaliza os símbolos e padrões existentes e expressa-se no mundo social, reinterpretando e recriando estes símbo- 
los de acordo com seus padrões culturais anteriores. ${ }^{9}$ A realidade organizacional é construída, então, a partir deste processo dialético. Como são os dirigentes e a elite da empresa que têm mais poder na determinação das diretrizes organizacionais, são os seus padrões culturais que constituem a cultura empresarial dominante.

E outros grupos, dentro da empresa, também influenciam na criação e recriação desta realidade organizacional, de forma proporcional ao poder que possuem.

O indivíduo procurará exercer influência sobre a organização na expectativa de obter satisfação pessoal adicional, dando origem a um processo contrário ao de socialização, chamado individuação. Pessoas dotadas de poder não formal nas organizações são em geral exemplos de processos de individuação bem-sucedidos. $A$ individuação desempenha um papel importante na renovação da organização. As organizações vivem muitas vezes sob condições de instabilidade e precisam ser influenciadas por seus membros, num esforço de adaptação a novas circunstâncias. A evidência mostra que, a longo prazo, a conformidade quase total tende a significar uma vitória de Pirro, comprometendo a sobrevivência da organização. Nem mesmo a rebelião é necessariamente catastrófica. Quando um processo deste tipo não termina em mudança organizacional profunda ou em demissão, muitas vezes o atacante feroz se transforma em defensor intransigente.

A forma de individuação, que em geral é mais benéfica para a organizaçăo, é o individualismo criativo, ou seja, a aceitação pelo indivíduo das normas básicas ou absolutamente essenciais para a organização, ou a rejeição de muito daquilo que é apenas relevante ou periférico. $\mathrm{O}$ indivíduo assim orientado consegue com freqüência exercer influência sobre a coletividade organizacional, o que pode significar muito, pois o relacionamento indivíduo-organização é um relacionamento entre desiguais. Em inúmeros casos, a organização beneficia-se de novas idéias.

No contexto atual, um dos papéis gerenciais é justamente o de administrador deste confronto, buscando continuamente a reconstrução de significados e valores compartilhados pelos membros da or- ganização, com o fim último de dar direção à empresa e influenciar positivamente sua performance. É importante notar os limites e o caráter controlado deste processo inovativo.

Os indivíduos que são reconhecidos como inovadores na empresa informacional, o fazem a partir dos valores constitutivos da cultura dominante. No caso de proporem uma nova tecnologia, que introduza uma nova perspectiva cultural,

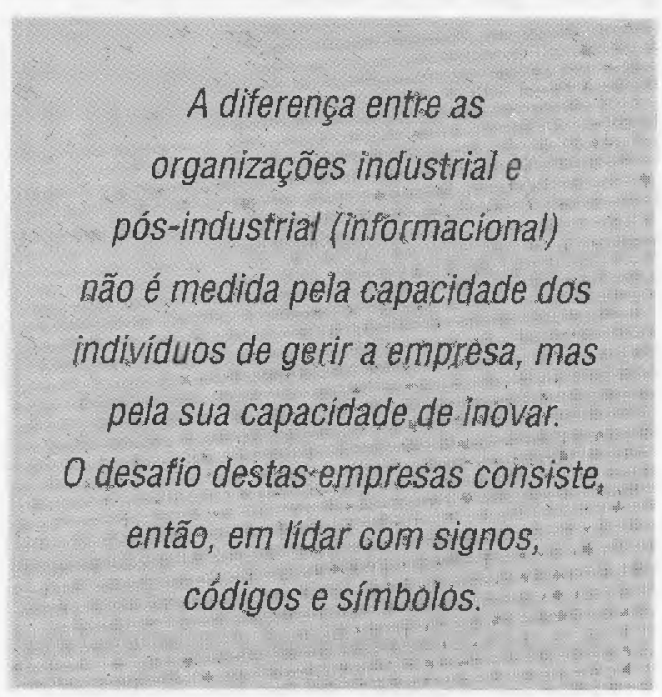

esta deverá ser aceita pelos dirigentes a fim de ser implementada, năo representando, portanto, uma ruptura no poder. E esta a administração participativa em recursos humanos hoje proposta, que reconhece o processo de individuação e procura controlá-lo, em função dos objetivos organizacionais.

A diferença entre as organizações industrial e pós-industrial (informacional) não é medida pela capacidade dos indivíduos de gerir a empresa, mas pela sua capacidade de inovar. $\mathrm{O}$ desafio destas empresas consiste, então, em lidar com signos, códigos e símbolos.

Dentro do paradigma interacionista, ou fenomenológico, os indivíduos são vistos como permanentemente engajados em processos interpretativos. Nesta perspectiva, os símbolos são como estruluras a partir das quais as pessoas concretizam e dão significado à sua vida. Gareth Morgan ${ }^{10}$ propõe o uso da metáfora da criação de significados compartilhados para explicar este processo. Wexler ${ }^{11}$ refere-se a esta mesma metáfora co-
9. BERGER, P.; LUCKMANN, A. A construção social da realidade. Petrópolis: Vozes, 1989; WEXLER, M. Pragmatism, interactionism and dramatism: interpreting the symbols in organizations. In: PONDY, L. (org.) Organizational symbolism. Greenwich: JAl, 1983

10. MORGAN, Gareth. Creating social reality: organizations as cultures. Images of Organization. Newbury: Sage, cap. 5 , 1986.

11. WEXLER, M. Op. cit. CHACON, J.M. Symbolic interacionism - an introduction on interpretation and integration. Englewood Cliffs, N.J.: Prentice-Hall, 1979. 
12. VASCONCELOS, I. IBM: O desafio da mudança, Revista de Administração de Empresas. São Paulo, v. 33, n. 2, mar./abr.1993.

13. ALTER, N. Logiques de l'entreprise informationnelle, Revue Française de Gestion. Paris, $n$. 74, p.28, 1989; VASCONCELOS, I. O market driven quality, a cultura organizacional e polftica de qualidade da IBM. São Paulo: EAESP/FGV, 1983 (dissertação de mestrado), onde a autora mostra os subgrupos e descreve a estrutura da IBM, que reproduz a divisão social por classes. Sobre mudança organizacional, ver WOOD JR., T. Mudança organizacional, ciência ou arte? São Paulo: EAESP/FGV, 1993 (dissertação de mestrado), onde o autor reflete sobre as dificuldades na implementacão de programas de mudança organizacional planejados. Ver FREITAS, M. E. Cultura organizacional - formação, tipologia $e$ impactos. São Paulo: Makron, 1991 onde a autora fornece subsídios teóricos para o estudo da cultura organizacional. mo metodologia de análise do processo de construção e mudança da realidade organizacional.

\section{Os grupos e subgrupos organizacionais}

As organizações não são homogêneas. Elas possuem subgrupos que interpretam a cultura organizacional de forma diversa, gerando subculturas. O interacionismo explica isto a partir do conceito de grupo de referência; ou seja, o grupo de pessoas que mediatizam a realidade para o indivíduo em seu processo de socialização primária. Pessoas da mesma classe social provavelmente compartilharão dos mesmos elementos culturais e uma visão de mundo similar. A organização, por sua vez, costuma reproduzir esta divisão social por classes. ${ }^{12}$

De acordo com Alter ${ }^{13}$, a empresa informacional possui três grupos de atores sociais que interagem neste processo de inovação e reinterpretação de valores e significados:

a. os gerentes médios ou funcionários que desempenham funções de liderança, que se caracterizam por seu conhecimento especializado em determinado assunto, sendo considerados $e x$ perts. Aceitando a cultura organizacional no que ela tem de fundamental, eles buscarão, através de um processo de individuação criativo, inovar e modificar a organização. Sua estratégia dentro da empresa é obter influência e reconhecimento social através deste processo;

b. os funcionários subordinados, que não dispõem de nenhum poder de mando. Eles controlam a parte administrativa, legal e formal da empresa e têm a tendência de se integrar aos novos sistemas desenvolvidos pelos gerentes, buscando coerência nos procedimentos administrativos;

c. os dirigentes e diretores da empresa, detentores de maior poder, que têm uma estratégia sutil no sentido de buscar o consenso a partir da promoção intencional de confrontos entre os dois outros grupos. Eles toleram em parte as estratégias desenvolvidas pelo grupo de gerentes médios, uma vez que elas são fundamentadas na racionalidade econômica e na inovação. Também apóiam algumas ações do grupo de funcionários administrativos, porque elas são um contrapeso em relação à ação gerencial e fornecem estabilidade à empresa, no sentido de evitar rupturas de poder.

A estratégia desenvolvida pelos dirigentes, de usar símbolos e elementos da cultura organizacional, a fim de difundir os valores e significados relativos à sua visão de como a organização deve ser e de como os seus membros devem se portar, encontra oponentes e resistências entre os gerentes de nível médio. Este grupo tende a participar e a inovar segundo seus próprios padrões. Eles produzem um modelo empresarial que obedece a uma racionalidade econômica própria e que permite uma mobilidade maior entre os membros da organização. Trata-se de uma ideologia de oposição em relação à da direção. $O$ "front cultural" entre estes dois grupos se organiza da seguinte maneira:

- à proposta dos dirigentes de criar, dentro de uma certa ordem, os gerentes médios opõem a criatividade na desordem, única forma de garantir sua autonomia e seu espaço;

- à referência ao consenso, por parte dos dirigentes, eles opõem o dissenso, que representa um meio de negociação aberta e não simplesmente uma fusão de interesses com o outro grupo;

- os gerentes defendem um espírito inovador e empresarial na organização, que estimula a autonomia e a luta por mais espaço e influência. Esta proposta opõe-se ao espírito de integração e equipe defendido pelos dirigentes;

- os gerentes opõem ao conceito de eficácia o conceito de eficiência; ou seja, defendem um bom resultado econômico global sem, no entanto, estarem comprometidos com os estritos objetivos anuais definidos a partir dos padrões fixados pelos dirigentes.

Existe também um quarto grupo composto pelos funcionários terceirizados. 
Alter, porém, não os leva em conta em sua análise dos jogos sociais dos grupos constitutivos da empresa informacional porque este grupo dispõe de pouco poder na organização para fazer parte do seu sistema social. Este grupo é agente da organização, no sentido que participa do processo de produção, não sendo entretanto um ator. Caso fosse possível aos terceirizados agir coletivamente enquanto grupo constituído, eles teriam um contra-poder muito maior e poderiam ter maior influência na organização. Os terceirizados são, ao contrário, um grupo pulverizado, excluído da vida organizacional. Estes indivíduos, apesar de conviverem na empresa cotidianamente e interagirem com seus membros, sentem-se e são, muitas vezes, discriminados.

Em uma organização complexa, composta por diversos subgrupos, que sofre fortes e constantes pressões de mudança, o desenvolvimento de instrumentos de socialização dos indivíduos, torna-se essencial.

Neste contexto, o treinamento e a aprendizagem, como instrumentos de mudança organizacional, ganham importância estratégica.

\section{O processo de socialização}

A socialização, pode ser entendida como o processo global pelo qual um indivíduo, nascido com potencialidades comportamentais de espectro amplo, é levado a desenvolver um comportamento bem mais restrito, de acordo com padrões de seu grupo. Esse conceito foi bastante utilizado na análise do impacto dos fatores culturais no desenvolvimento da personalidade individual. No que se refere às organizações, o conceito vem sendo empregado em termos de doutrinação e treinamento, reportando-se ao que Edgar Schein chamou de "o preço de participar".

A socialização organizacional deve ser vista como um processo contínuo, que começa antes mesmo da entrada neste sistema, já que outros sistemas sociais inculcam, desde o nascimento, valores e normas conformes ao comportamento aceitável em organizações complexas. Não pára aí, porém, o processo; continua durante toda a permanência na organização. Nas palavras de Caplow, em 1964:
"Os comportamentos apropriados a uma posição organizacional nāo são adquiridos de uma vez e completamente, quando a posição é assumida, mas são aprendidos e reaprendidos durante o periodo de uma carreira." 14

O processo de socialização é responsável pela lealdade, comprometimento, produtividade e núvel de rotatividade. A estabilidade organizacional depende bas-

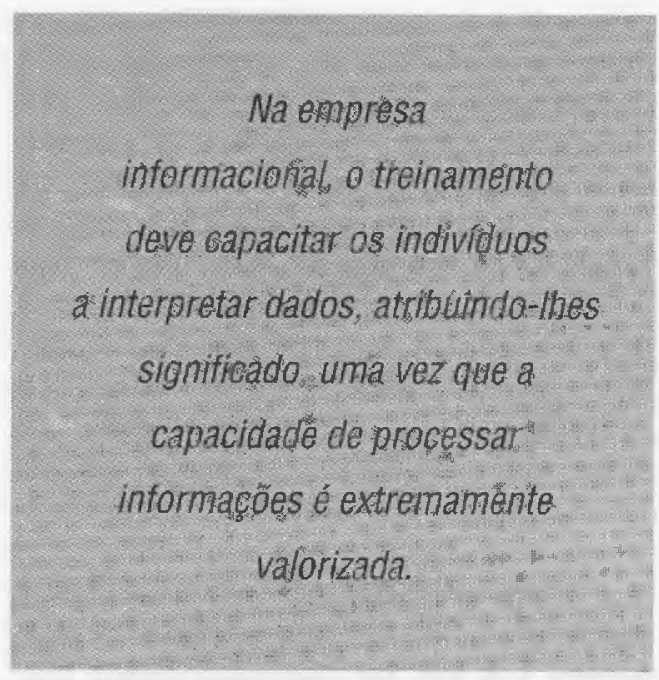

tante da socialização, o que implica forte transmissão de ideologia. A organização é com freqüência amada e odiada a um só tempo, algo semelhante ao que alguns autores chamam de amor-fusão. ${ }^{15}$

Como um grande número de processos, também a socialização organizacional apresenta suas fases. Não é difícil identificar a fase de chegada, quando um indivíduo traz para uma nova organização ou posição um conjunto de valores, atitudes e expectativas, conjunto este que será reconstruído no interior da organização. Também não é difícil identificar uma fase de confronto, quando o conjunto de atitudes e predisposição do indivíduo encontra os desejos e valores prevalentes na organização. É a fase em que o indivíduo se submete a reforço e confirmação, a ausência de reforços, ou ainda a reforços negativos, isto é, a reações de aprovação, indiferença ou punição, por ele percebidas como vindas da organização. Finalmente, há uma fase de mudança e aquisição, quando o indivíduo começa a agir de forma a aprender e a desenvolver comportamentos e idéias modificadas.
14. CAPLOW, T. Principles of organization. New York, Hartcourt: Brace \& World, 1964, p. 169. Apud PORTER, M. et alii. Behavior in organization. McGraw-Hill, 1975, p. 162

15. ENRIQUEZ, E. La notion de pouvoir, L'Economie et les sciences humaines. Paris, Dunod, t. 1: Thẻories, conceptes et méthodes, p. 257-306. Ver também alguns estudos de organizaçōes orientados pela metáfora de organizações como prisôes psíquicas (paradigma radicalhumanista). Para tanto, ver MORGAN, G. Exploring Plato's cave: organizations as psychic prisons. Images of organization. Newbury: Sage, 1986. 
16. SCHEIN, Edgard. The Individual, The Organization and the Career. A Conceptual Scheme. Journal of Applied Behavioral Science, n.7, p. 401-26, 1971. Apud PORTER, M. Op. cit., p. 167.

17. BRESLER, Ricardo. Organização e programas de integracão: um estudo sobre a passagem. São Paulo: EAESP/FGV, 1993 (Tese de mestrado, onde o autor faz um estudo crítico sobre treinamento e programas de trainees).

18. LIPPIT, G: NADLER, $L$. Emerging roles of the training director. Training and Development Journal, v. $33, n$. 6 , junho 1979, p.26-30; WARNOTTE, Georges. Ressources Humaines: L'evaluation ligotée. Revue Française de Gestion. Set./Out. 1979.

19. DEAL, T ; KENNEDY, A. Op. cit.

20. Estudos nesta linha são desenvolvidos nas organizacões baseando nos estudos de BURKE, K. Dramatism and Develop ment. Barre, Clak University Press, 1972; BURNS, Theatricality. New York: Harper and How, 1972.

21. WEXLER, M. Op. cit., p. 250.

22. LAWLER, Edward; HACHMANN, R. Op. cit.

23. SEGNINI, Liliana. Liturgia do poder - trabalho e disciplina. São Paulo: Educ, 1988, onde a autora faz um estudo crítico sobre os métodos de controle social do BRADESCO.

24. PAGÈS, Max. Poder nas organizações. São Paulo: Atlas, 1993; JUNG, Karl. Man and the symbols. Londres: Aldus Books, 1964; MARCUSE, 0. O homen unidimensional. Boston: Beacon Press, 1964; FREUD, S. General introduction to Psychoanalysis New York: Liveright, 1922 FROMM, Erich. Fear of freedom. Londres: Routledge \& Keagan Paul, 1942; MORGAN, G. Op cit.
Algumas destas aquisições dizem respeito a uma nova auto-imagem, isto é, a uma nova percepção de si mesmo desenvolvida pelo indivíduo, como resultado de sua interação ao seu papel organizacional. Dizem respeito também ao estabelecimento de novos relacionamentos freqüentemente em prejuízo de relacionamentos antigos, à recepção, aceitação e internalização de novos valores e a novos conjuntos de comportamentos, alguns deles essenciais para a permanência na organização e para a obtenção de algumas recompensas. Em termos de necessidade de aquisição, Schein ${ }^{16}$ distingue três tipos de comportamentos. Em primeiro lugar, há os comportamentos que podem ser chamados pirrotais, que são aqueles que a organização considera tão essenciais que, na ausência de sua adoção, o indivíduo não estará preenchendo padrões mínimos de desempenho. Em segundo lugar, há formas de comportamento consideradas pela organização como desejáveis mas não absolutamente necessárias. São os comportamentos relevantes. Por fim, há comportamentos permitidos pela organização que eventualmente podem vir a tornar-se relevantes. São os comportamentos periféricos.

A organização promove a socialização de várias formas.

A seleção é um método que com freqüência constitui instrumento poderoso. $\mathrm{O}$ treinamento ${ }^{17}$, à medida que desenvolve as habilidades técnicas ligadas de modo direto a tarefas para o desempenho de funções, facilita a mudança de comportamento, em termos de atividades diretamente funcionais. $\mathrm{O}$ treinamento também age sobre a mudança de auto-imagem, sobre a criação de novos relacionamentos e novos valores; isto é, no desenvolvimento de habilidades normalmente chamadas adaptativas. ${ }^{18}$

Além disso, na empresa informacional, o treinamento deve capacitar os indivíduos a interpretar dados, atribuindo-lhes significado, uma vez que a capacidade de processar informações é extremamente valorizada.

O gerente de treinamento pró-ativo desenvolve programas de socialização dos indivíduos via treinamento ou aprendizado através do uso de elementos simbólicos.
Segundo Deal e Kennedy ${ }^{19}$, eles incentivam a participação e a inovação por parte de seus subordinados. Reforçam as crenças organizacionais e o espírito de que "somos um time especial e juntos obteremos o sucesso". Eles se visualizam como atores, roteiristas, diretores e autores, no "drama" cotidiano de controle e planejamento da ação dos membros da organização. ${ }^{20} \mathrm{De}$ uma forma dramática, eles nunca perdem um momento para reforçar os aspectos da cultura organizacional. Deve-se ressaltar que, na maioria das vezes, eles realmente acreditam nesta cultura organizacional e nos valores por ela representados. Os atores sociais incorporam os papéis que representam. ${ }^{21}$ Sendo expressivos, eles normalmente conseguem impressionar sua "platéia": os membros da organização. Encorajam os ritos e celebrações de um subgrupo organizacional, procurando relacioná-los com a cultura organizacional mais ampla.

Estes simbolic managers, legitimando a subcultura como parte da cultura organizacional mais ampla e valorizando-a no sentido de ressaltar as contribuições que ela dá para a cultura organizacional em termos de cerimônias, ritos e significados, buscam a coesão e a reafirmação dos valores constitutivos desta cultura mais ampla.

Os sistemas de controle são responsáveis pela criação de resistências porque são vistos como frustradores de satisfação em diversas áreas, porque com freqüência reduzem o grau de competência especializada necessária à execução, ou automatizam, padronizam ou enrijecem o trabalho. São particularmente relevantes as interferências nas áreas de status, autonomia e segurança. ${ }^{22}$ Os sistemas de trabalho costumam criar experts, em prejuízo de outras pessoas que passam a resistir.

Muitos autores têm destacado como os elementos culturais são utilizados como forma de dominação nas empresas. ${ }^{23} \mathrm{Os}$ trabalhos de Max Pagès ${ }^{24}$, que parte do enfoque psicanalítico dos símbolos nas organizações e outros trabalhos baseados em Jung, Erich Fromm, Freud são significativos desta linha, denominada radicalhumanista. Jung propôs o uso dos símbolos para fazer o processo inverso, ou seja, ser um elemento de libertação do indivíduo, no sentido de que estes são a chave 
para o autoconhecimento e liberação de elementos inconscientes, através do processo de individuação. Também neste sentido, Gilbert Durant ${ }^{25}$ denuncia a perda da capacidade de simbolização do homem moderno propondo uma "pedagogia do imaginário", que utilizaria os símbolos para recuperar a capacidade de expressão dos indivíduos. Alguns autores denunciam a chamada "esquizofrenia social do modernismo", ou perda da capacidade de simbolização do homem moderno. ${ }^{26}$

Os radicais-estruturalistas, a partir dos trabalhos de Marx ${ }^{27}$, e também os weberianos radicais, levantam o caráter ideológico dos símbolos como fonte de dominação explorando mais detalhadamente a dimensão macrossocial.

Compreendendo como se dá o processo de construção da realidade organizacional e estudando as ações de socialização dos simbolic managers, pode-se analisar de uma forma crítica a implementação da gestão participativa de recursos humanos, tão em voga atualmente.

\section{A dimensão macrossocial e a dimensão microssocial}

É preciso lembrar que os processos or ganizacionais reproduzem fortemente as necessidades do sistema social em que a organização se insere, e que seus participantes são levados a agir de acordo com a lógica desta reprodução. As organizações não são homogêneas; são complexas. Ioffman e Maier, em 1959 e 1961, descobriram que grupos compostos de membros com interesses diferentes tendiam a produzir soluções de melhor qualidade para uma grande variedade de problemas, do que grupos homogêneos. ${ }^{28}$

A influência macrossocial ${ }^{29}$ é exercida por uma infinidade de meios. Convém lembrar que, em uma organização, todos os membros são parte de um sistema social maior, e que não deixam de sê-lo quando estão no interior das organizações. Esses indivíduos fazem e refazem constantemente as transações entre a organização e o meio ambiente social e vice-versa. Inúmeros autores têm chamado atenção para este fato, e de modo muito especial para as chamadas transações através das fronteiras permeáveis da organização, o que tem sido sublimado pelos teóricos de sistema em geral e, em particular, pelos pesquisadores do Tavistock Institute de Londres. Além disso, as organizações constituem nada menos que o essencial da superestrutura político-institucional de qualquer formação social. Assim, é ao núvel das organizações complexas que se realizam as relações de produção e das forças produtivas, incluídas evidentemente, as formas de cooperação, que representam a base material da sociedade, além de constituírem aparelhos

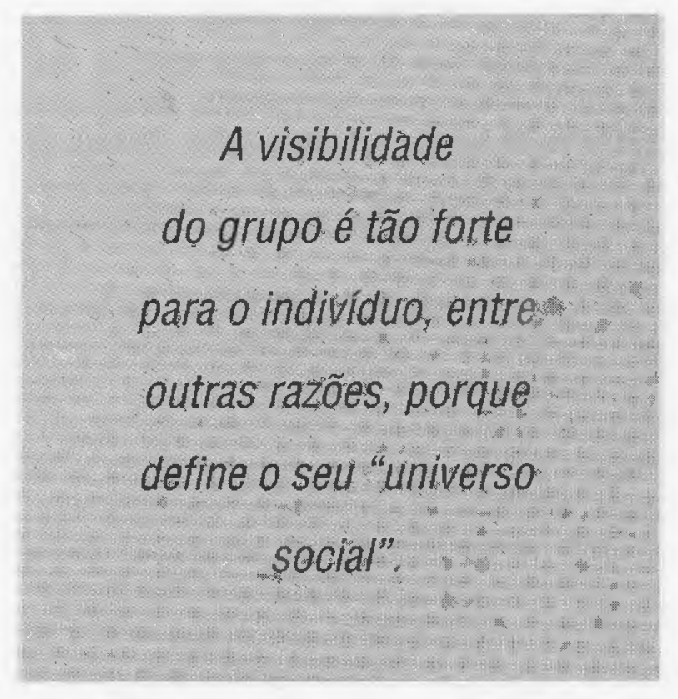

ideológicos por excelência. Nada mais lógico do que a realização e a reprodução a nível organizacional daquilo que ocorre em um plano social maior, no qual, sem dúvida, as organizações têm um papel central.

Gareth Morgan ${ }^{30}$ sistematiza o estudo das organizações como sistemas políticos, lidando com a questão do conflito de interesses e dando especial ênfase à dimensão do poder. ${ }^{31}$

O comportamento grupal tem sido exaustivamente estudado pelos teóricos das organizações e pelos psicólogos sociais, em especial a partir de Kurt Lewin. Modernamente, a tradição psicanalítica também tem-se preocupado com o grupo de forma bastante significativa ${ }^{32} \mathrm{O}$ trabatho de Bion sobre o comportamento grupal, por exemplo, parece ser algo incorporado de modo definitivo aos esforços de compreensão dessa sorte de processos.

Outras correntes de pesquisa bastante diversas vêm-se também ocupando dos grupos de trabalho: na França, o grupo de Análise Institucional, e nos Estados
25. Ver DURAND, G. A imaginação simbólica. Sāo Paulo: Cultrix, 1989.

26. HARVEY, David. Condiçāo Pós-Moderna. Sāo Paulo: Loyola, 1992; BERMAN, Marshall. Tudo que é sólido desmancha no ar - $A$ aventura da modernidade. Sāo Paulo: Companhia das Letras, 1986; WOOD JR. Fordismo, Toyotismo e Volvismo - Os Caminhos da Indústria em Busca do Tempo Perdido. Revista de Administração de Empresas. Sāo Paulo, v. 32 , п. 4, p. 6-18, set./out. 1992.

27. MARX, K. Economic and pholosophical manuscripts. Early writings. Harmonsdsworth: Penguin, 1975; BENDIX, Work and Authoritary Industry. New York: Wiley, 1956; WALTER, Gordon; PONDY, L. (org.). Psyche and Symbol, Organisational Symbolism. Bervely Hills, Sage, 1983; ABRAVANEL, Harry. Mediatory Myths in the Service of Organizational Ideology. Apud PONDY, L. (org.) Organisational Symbolism. Bervely Hills, Sage, 1983; MORGAN, Gareth. Op. cit.

28. THOMAS, Kenneth. Conflict and conflic management. In: DUNNETE, M. D. Handbook of industrial and Organizational Psychology. Chicago: RandMcNally , 1976 .

29. Em uma abordagem funcionalista, pode-se ver a metáfora das organizaçōes como organis mos. Ver MORGAN, Gareth. Nature intervenes: organizations as organisms, Images of Organizafion. Newbury: Sage, 1986, p.3971; MOTTA, Fernando P. Teoria das Organizaçōes, Evoluçāo e Critica. São Paulo: Pioneira, 1986.

30. MORGAN, G. Idem, ibidem.

31. MiLLER, E,; RICE,A. Systems of organization. Londres: Tavistock, 1967; ANSART, Pierre. Ideologias, conflito e poder. São PauIo: Zahar, 1978. O autor estuda também neste livro a eficácia do nivel simbólico como fonte de dominação nas organizaçōes, cap. 8; MORGAN, Gareth. Interests conflict and power. Images of Organization. Newbury, Sage, 1986, p.141-94.

32. 0 paradigma radical-humanista descrito por Gareth Morgan em seu tivro Organizational Symbolism. MORGAN, Gareth. Op. cit. SMIRCICH, Linda. Steding Organizations as Cultures. In: MORGAN, G. (org.) Beyono Method: Strategies for Social Research, Bervely Hills: CA, Sage, 1983. 
33. BEER, Michel. Technology of organization development. In: DUNNETE, Marvin. Op. cit., p.955. Sobre a organização informal e seus relacionamentos com subgrupos organizacionais ver MORGAN, Gareth. Op. cit. p. 112-34.

34. Ver HACKMAN, J. Richard, Group Influences on Individuals. In: DUNNETE, Marvin. Op. cit., p.1459.

35. PORTER,Michael. The Competitive Advantage of Nations, New York: Free Press, p.33-46.

36. STARBUCK,W. Organizations and their environments. In: DUNNETTE, Marvin. Op.cit., p.1078-80.

37. Ver estudos ligados ao paradigma interacionista aplicados à administração e derivados da tradição fenomenológica, que dizem que toda a interpretação está ligada a seu contexto de significados. A "sense-make methapor" ou significados compartilhados permite estudar esta questão. Ver WEXLER,M. Pragmatism, interactionism and dramatism: interpreting the symbols in organizations. In: PONDY, L. (Org.) Organizational symbolism. Greenwich: JAl, 1983; FORGHIERI, Yolanda. Psicologia fenomenológica, fundamentos, método e pesquisas. São Paulo: Pioneira, 1993.

38. PAGÉS, Max. Poder nas Organizações. São Paulo: Atlas, 1993.

39. Ver, a este respeito, VASCONCELOS, Flávio. Direito, trabalho e burocracia. São Paulo: EAESP/FGV, 1989 (dissertação de mestrado), onde 0 autor descreve de forma crítica a burocracia e 0 autoritarismo presentes na justiça do trabalho brasileira e nas organizações em geral, salientando seu papel como forma de dominação social.

40. MERTON,Robert. Sociologia, teoria e estrutura. São Paulo: Mestre Jou, 1970, p. 275.
Unidos, o grupo do Desenvolvimento Organizacional. Michael Beer, referindose às intervenções intergrupais afirma: "O grupo primário é, provavelmente, o mais importante subsistema do interior de uma organização. Sua importância na configuração do comportamento organizacional faz recordar a visão de Likert da organização com uma série de pequenos grupos ligados por individuos que são membros em um grupo e líderes em outro. Não é, portanto, surpreendente que o desenvolvimento grupal tenha recebido tanta atenção" ${ }^{\prime 33}$ Como citado anteriormente, uma das funções dos simbolic managers é atuar como elementos de ligação entre os diversos grupos, a fim de buscar a integração e a aceitação dos padrões contidos na cultura organizacional mais ampla da empresa.

A visibilidade do grupo é tão forte para o indivíduo, entre outras razões, porque define o seu "universo social". Faz sentido declarar que "um conjunto de afirmações grupais de uma pessoa pode ser visto como definidor de sua posição, em uma organização, de modo análogo à forma pela qual a posição espacial de uma pessoa define sua posição no universo físico. Nos dois casos, a filiação e a posição espacial afetam fortemente a quantidade e o caráter substantivo dos estimulos aos quais as pessoas estão expostas nas atividades cotidianas". ${ }^{34}$

O que ocorre no ambiente social é menos visível, porque a própria relação organização-ambiente, de que tanto se vem falando (principalmente agora, em que a racionalidade econômica da inovação constante divulgada por Porter ${ }^{35}$, entre outros, propõe uma empresa que, além de reagir ao ambiente, deve influenciálo), tem significados tão vagos que chega a ponto de comprometer o conteúdo dos conceitos. Sobre isto é esclarecedora a colocação de William Starbuck ${ }^{36}$, segundo o qual: "em nível não desprezível, um ambiente organizacional é uma invenção arbitrária da própria organização" e: "o mesmo ambiente percebido por uma organização como imprevisivel, complexo e evanescente, pode ser visto por outra organização como estático e facilmente compreensivel". ${ }^{37}$

Este é o universo do controle social nas organizações, um universo que envolve necessariamente alguns dos aspectos essenciais de qualquer organização, porque é, ele próprio, essência de qualquer orga- nização complexa. Um universo que envolve relações de produção, formas de organização do trabalho, inculcação ideológica, repressão, dinâmica grupal e identificação, conforme detectaram diversos autores, entre eles Lloyd Warner, antropólogo, que percebeu a importância da dimensão psicológica na explicação do sucesso profissional em organizações, e que tanta influência exerceu sobre a sociologia americana.

Esta abordagem também pode ser vista em Max Pagès, que desenvolveu trabalhos importantes neste campo, focalizando o papel da canalização de energia libidinal no controle social de organizações. Atualmente, Pagès, é considerado um dos pesquisadores mais importantes dentro do paradigma radical-humanista aplicado ao estudo de organizações. ${ }^{38} \mathrm{O}$ controle social envolve poder e autoridade, pelo simples fato de constituir a própria efetivação da dominação. Por esta razão, a preocupação com o controle social nas empresas é a crítica de como a autoridade se estrutura burocraticamente em organizações tradicionais. ${ }^{39}$

\section{MERTON, SELZNICK E GOULDNER}

\section{MERTON}

Para Robert King Merton, a temática do controle social é tratada via crítica da burocracia, inaugurando uma longa tradição. A burocracia é vista como portadora de funções e disfunções, e isto nos ajudará a perceber as diferenças entre o "tipo ideal" e a realidade. Para ele, a burocracia pode ser estudada em termos de seu direcionamento para a precisão, a confiança e a eficiência, e de suas imitações para alcançar esses fins. A análise de Merton parte da exigência de controle, por parte da burocracia, para seu funcionamento satisfatório. Assim, ela exerce pressão sobre o funcionário, em termos de comportamento "metódico, prudente e disciplinado". Tal pressão decorre da necessidade de um alto grau de confiança na conduta dos funcionários. ${ }^{40}$ Destaca-se, portanto, a relevância da disciplina. Esta só se realiza se os padrões estabelecidos forem sustentados por sentimentos que garantam a dedicação dos funcionários aos deveres burocráticos. 
Em última instância, portanto, a eficácia da burocracia depende da inculcação de atitudes e sentimentos apropriados a seu funcionamento. ${ }^{41}$

Ocorre, porém, que tais sentimentos inculcados tendem a se intensificarem mais do que o necessário, diminuindo o número de relações personalizadas, substituídas pelo apego excessivo às exigências dos procedimentos burocráticos, estimulado pelo próprio planejamento da vida burocrática, isto é, de uma carreira graduada, caracterizada por promoções, pensões, reajustes salariais etc. Ao funcionário cabe, portanto, a adaptação de pensamentos, sentimentos e ações, com vistas às perspectivas oferecidas pela carreira. Isto tende a estimular o seu conformismo, conservadorismo e tecnicismo. ${ }^{42}$ Tal inculcação, estimulada pelo formalismo dos pequenos procedimentos, leva ainda à transferência da identificação com os meios, representados pela conduta exigida pelas normas. A submissão à norma, que passa de meio a fim em si mesma, gera, a nível da organização, um deslocamento de objetivos. Em termos de "virtudes" do burocrata, leva à rigidez de comportamento e à dificuldade no trato com o público, a quem a burocracia deve atender. ${ }^{43}$

Tal dificuldade é estimulada pela categorização, isto é, pela tendência ao enquadramento de grande variedade de casos particulares a algumas poucas categorias de tratamento. $\mathrm{O}$ burocrata, longe de ser estimulado ao comportamento inovador, é estimulado à segurança e ao conforto oferecidos pela obediência cega a regulamentos. Previsibilidade e rigidez de comportamento caminham, portanto, de modo paralelo. Por sua vez, ao mesmo tempo em que há uma redução das relações personalizadas, dá-se o desenvolvimento do esprit de corps, a autodefesa do grupo burocrático perante a sociedade e seu público. O desenvolvimento dessa autodefesa burocrática tende a aumentar a rigidez dos funcionários, cônscios de seus interesses comuns e em busca de defendê-los.

Na linha de Merton, a principal conseqüência da rigidez de comportamento é o surgimento de uma organização informal defensiva em face de qualquer ameaça à integridade do grupo, o qual busca aten- der a seus objetivos, muito mais do que aos dos clientes, para cujo serviço a burocracia existe. Tal fato em geral implica o conservadorismo, bem como a redução ao mínimo de contatos pessoais com os clientes, seguida do tratamento impessoal de assuntos que para estes tenham importância pessoal, além do aparecimento do conflito entre o burocrata, que se sente investido da autoridade de toda a organização, e o cliente que, julgando-se muitas vezes socialmente superior a ele, também possam adotar uma atitude dominante. ${ }^{44}$ A percepção de todo o modelo desenvolvido por Merton fica bastante facilitada pela análise do gráfico 1 abaixo.

Nos anos oitenta e noventa, desenvolveu-se nas organizações a chamada "Cultura da Qualidade " 45 que defende uma organização que se integra horizontalmente, com a diminuição de níveis hierárquicos e a desburocratização, a fim de processar melhores informações, agindo sobre o ambiente. Esta abordagem "neo-
41. MERTON,Robert. Estrutura burocrática e Personalidade. In: CAMPOS, Edmundo. (org.) Sociologia da Burocracía. Rio de Janeiro: Zahar, 1966.

42. MERTON, Robert. Idem, ibidem.

43. MERTON, Robert. Idem, ibidem.

44. MERTON. Robert. Idem, ibidem.

45. FLEURY, Maria Teresa. Cultura Organizacional e Estratégias de Mudanças: Recolocando estas Questões no Cenário Brasileiro Atual. Revista de Administraçāo. São Paulo: USP, V. 26, ก. 2, p.3-11, abril-junho 1991.

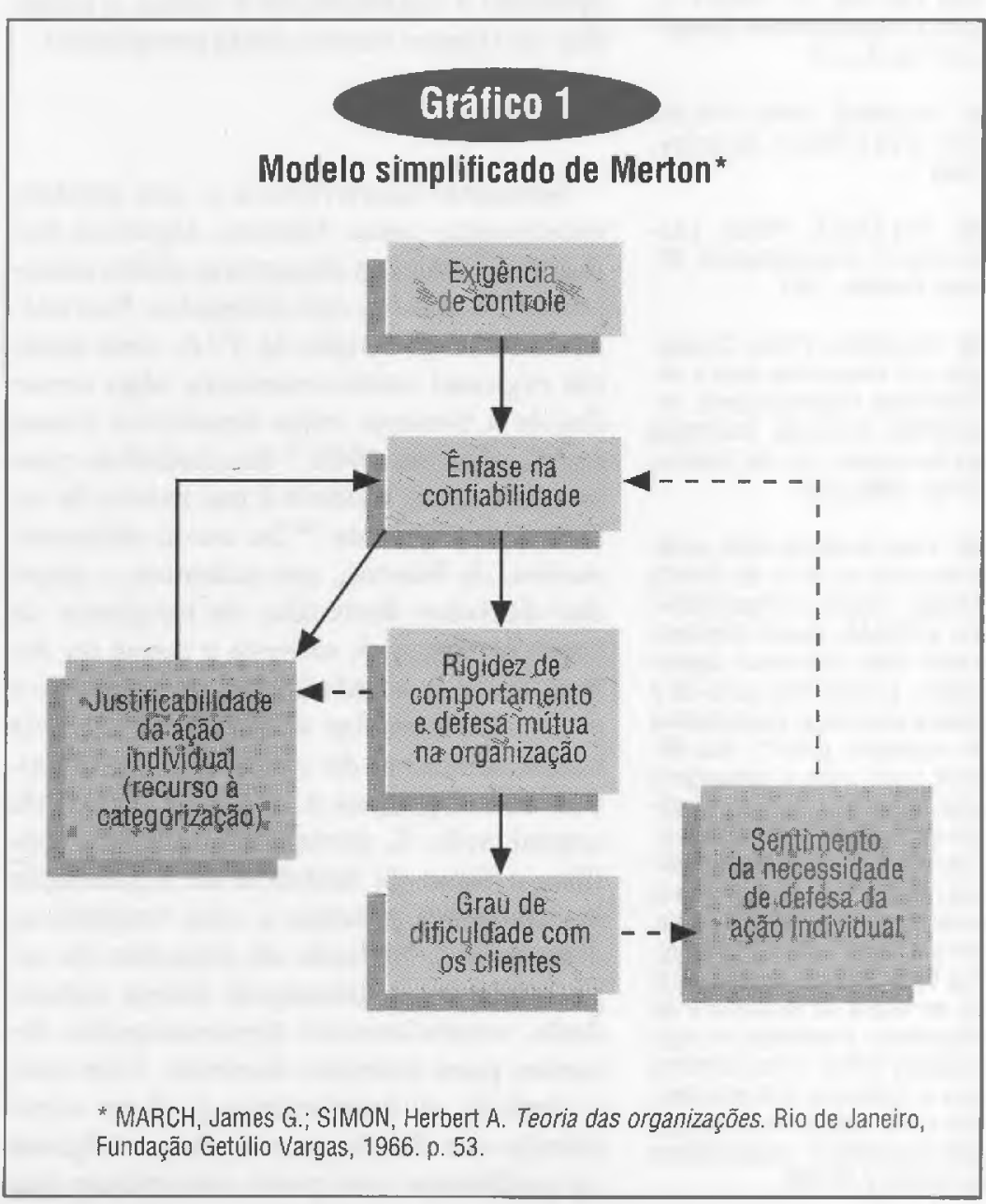


46. CAMPBELL,J. Miths to Live By. New York: Viking, 1972; DANDRIDGE,T. Symbols Function and Use. In: PONDY, L. (org.) Organizational Symbolism. Op.cit., p.71.

47. SELZNICK, Philip. TVE and The Grass Roots. Berkeley, 1949.

48. SELZNICK, Philip. Leadership in Administration. Illinois: Evanton, 1957.

49. SELZNICK, Philip. Cooptação: um mecanismo para a estabilidade organizacional. In: CAMPOS, Edmundo. Sociologia da Burocracia. Rio de Janeiro: Zahar, 1966, p.99.

50. Estes modelos estão sistematizados no livro de Gareth Morgan Images of Organization. Ver MORGAN, Gareth. Mechanization takes command: organizations as machines, p.19-39 e Nature intervenes: organizations as organisms, p.40-71. Nos últimos anos, com o paradigma pós-industrial e com a estratégia da inovação e da qualidade, fala-se em organizacōes pró-ativas, que influenciam no meio ambiente, não só reagindo a ele, em um alargamento do paradigma funcionalista. Surge, além da metáfora da máquina e do organismo, a metáfora de organizações vistas como cérebros que processam informações. Ver neste mesmo livro Toward self-organization: organizations as brains, p.79-105. funcionalista" corresponde ao paradigma pós-industrial que, conforme citado, possui um tipo de racionalidade econômica antiburocrática, que defende a criatividade e a inovação. A empresa deve processar informações com rapidez, auto-regulando-se. A imagem utilizada pelos teóricos desta linha refere-se às organizações como cérebros, que devem aprender a aprender. Os empregados devem agir em função dos desejos e necessidades de seus clientes internos e externos, desenvolvendo relações pessoais com os mesmos.

Joseph Campbell ${ }^{46}$, denuncia em seu estudo como os símbolos podem ser usados como fonte de poder nas organizações. $O$ autor utiliza a definição de símbolos de Merton, que afirma que "o verdadeiro símbolo não indica apenas um objeto. Ele contém em si mesmo a estrutura que dirige a nossa mente na formação de uma nova consciência do significado intrínseco da vida e da realidade." Campbell faz uma análise segundo o paradigma radical-humanista aplicado a organizações e utiliza o trabalho de Merton dentro desta perspectiva.

\section{SELZNICK}

Selznick desenvolveu o seu modelo mostrando, como Merton, algumas formas pelas quais a burocracia acaba alcançando resultados não desejados. Sua análise deriva do estudo da TVA, uma agência regional norte-americana algo semelhante à Sudene, cujos resultados foram publicados em $1949 .{ }^{47} \mathrm{Em}$ trabalhos posteriores, o seu modelo é um marco de referência subjacente. ${ }^{48}$ De modo diferente, porém, de Merton, que salientou o papel das decisões derivadas da exigência de controle, Selznick salienta o papel da delegação de autoridade. Seu pressuposto é que as burocracias se caracterizam pela busca constante da integração de objetivos de subgrupos à doutrina oficial da organização. É, portanto, o reino do conflito, o reino da tentativa de legitimação de interesses parciais e, com freqüência, divergentes. Partindo do princípio da especialização, a hierarquia delega autoridade, estabelecendo departamentos diversos para assuntos diversos. Com isto, é verdade, os funcionários ganham experiência em domínios restritos, reduzem os problemas nos quais concentram sua atenção e aperfeiçoam a forma de tratálos. Assim, a prática da delegação de autoridade, que não deve ser vista estritamente como delegação de controle, mas como delegação de funções, é amplamente estimulada. Selznick observa, porém, que alguns problemas decorrem dessa prática.

Em primeiro lugar, deve-se lembrar que não só o teor das decisões organizacionais tende a se modificar, como a produção de ideologias de subgrupos tende a se desenvolver. Assim, sob a pressão de seus ruralistas, a TVA alterou, gradualmente, um aspecto significativo de seu caráter de agência conservadora, contradizendo seus objetivos estabelecidos. Com efeito, refletindo atitudes e interesses proprios, o grupo rural da TVA lutou contra a política de utilização de terras de propriedade pública, contribuindo de forma efetiva para a alteração da política original da TVA a esse respeito. Aliás, a busca inflexível de interesses próprios, por parte do grupo rural da agência, acabou por envolvê-la em um conflito com o Departamento do Interior, a nível da alta administração central federal. ${ }^{49}$

Em termos simples, a análise de Selznick indica que a delegação de autoridade, bifurcando interesses mediante a especialização, e propiciando o desenvolvimento de ideologias grupais ou subgrupais, acaba por aumentar, no interior dos próprios membros dos subgrupos, a internalização de seus objetivos, processo em que desempenham um papel básico nas decisões de rotina.

Como estas dependem, em primeira instância, dos critérios estabelecidos pela organização, a própria operação das tarefas especializadas será responsável pela criação de precedentes, que acabarão por constituir a reação comum a determinadas situações, transformando-se, portanto, em padrões repetitivos de conduta e internalizando cada vez mais os objetivos da burocracia, como prefere Selznick. A busca de objetivos desejados pode, portanto, transformar-se facilmente na realização de objetivos inesperados e indesejados pela burocracia, entendida em termos das diretrizes estabelecidas pelo comando monocrático.

Embora a análise de Selznick seja interessante e realista, escapa-lhe a verdadeira 
percepção da burocracia enquanto poder e de sua decorrência: a lógica do comportamento burocrático. Com efeito, o padrão que a análise de Selznick torna transparente oculta o fato de que a burocracia existe pelos burocratas e para os burocratas. Assim, a multiplicação de tarefas especializadas, cargos e departamentos são a própria raison d'être dos burocratas. Em última instância, quanto mais cargos, melhores as condições de aumento do poder burocrático, o que, a nível de sociedade global, significaria que, quanto mais organizações burocráticas, mais satisfeitos os burocratas. Isto é evidente e relaciona-se com a própria carreira burocrática, sua mobilidade vertical e horizontal.

Na verdade, já em Selznick, tanto quanto em Merton, vamos encontrar a contradição fundamental que permeia a teoria da organização funcionalista-sistêmica: a mediação entre a teoria e a realidade feita por modelos ${ }^{50}$ que, quando mais claros, menor valor explicativo apresentam, e quanto mais ricos, mais perdem esse valor. Isto ocorre porque o modelo é seletivo; parte de hipóteses preferenciais, sem estar inserido em uma teoria histórica. Assim, o valor dos critérios que presidem a escolha das variáveis em jogo é que dá o fundamento do modelo. Selznick não conscguc cscapar ao aspecto central da crítica administrativa da burocracia: a expressão da razão do poder, muito mais do que do poder da razão. ${ }^{51}$ Tal conceito faz pensar duplamente em Veblen. Primeiramente, porque ele foi um dos inspiradores de Merton, com seu conceito de "incapacidade treinada", e em segundo lugar porque é dele a afirmação: "A autenticidade e a dignidade sacramentais não pertencem à tecnologia, à ciência moderna, nem às atividades mercantis." 52 De qualquer forma, porém, para perceber bem o modelo de Selznick, nada mais nútido que o gráfico 2 ao lado.

Em relação à integração dos subgrupos à doutrina oficial da organização, alguns autores baseiam-se nos estudos de Selznick como fonte de sua análise.

Joanne Martin e Melanie Powers ${ }^{53}$ descrevem como os líderes organizacionais escolhem valores-chave que devem embasar a ação organizacional e, em segui$\mathrm{da}$, procuram criar uma estrutura social que incorpore estes valores. Descrevem ainda como símbolos, mitos, sagas e histórias são utilizados pelos líderes para divulgar a missão e as diretrizes da organização para os diversos subgrupos que a compõem. Wilkins, com base no livro de Selznick, Leadership in Administration, desenvolve esta mesma linha de análise.

\section{GOULDNER}

Segundo o modelo de Alvin Gouldner, a origem das perturbações no equilibrio da organização como sistema maior, derivadas de técnicas de controle destinadas a manter o equilibrio em um subsistema, está na adoção de diretrizes gerais e impessoais como forma de solução para o controle exigido pela cúpula burocrática. Naturalmente, a despersonalização diminui a visibilidade das relações de poder, o que se relaciona de modo direto com o papel do supervisor. Com isto, altera-se o nível de tensão interpessoal no grupo de trabalho.
51. TRAGTEMBERG, Maurício. Burocracia e ldeologia. São Pauło, Ática, 1974, p. 28.

52. VEBLEN, Thorstein. Teoria da Empresa Industrial. Porto Alegre: Globo, 1966, p. 202.

53. MARTIN, Joanne; POWERS, Melanie. Truth or corporate propaganda: the value of a good war story. In: PONDY, L. (org.) Organizational Symbolism. Op.cit.; WILKINS, Alan. Organizational stories as symbols which control the organization. In: PONDY, L. (org.) Organizational Symbolism. Op.cit.

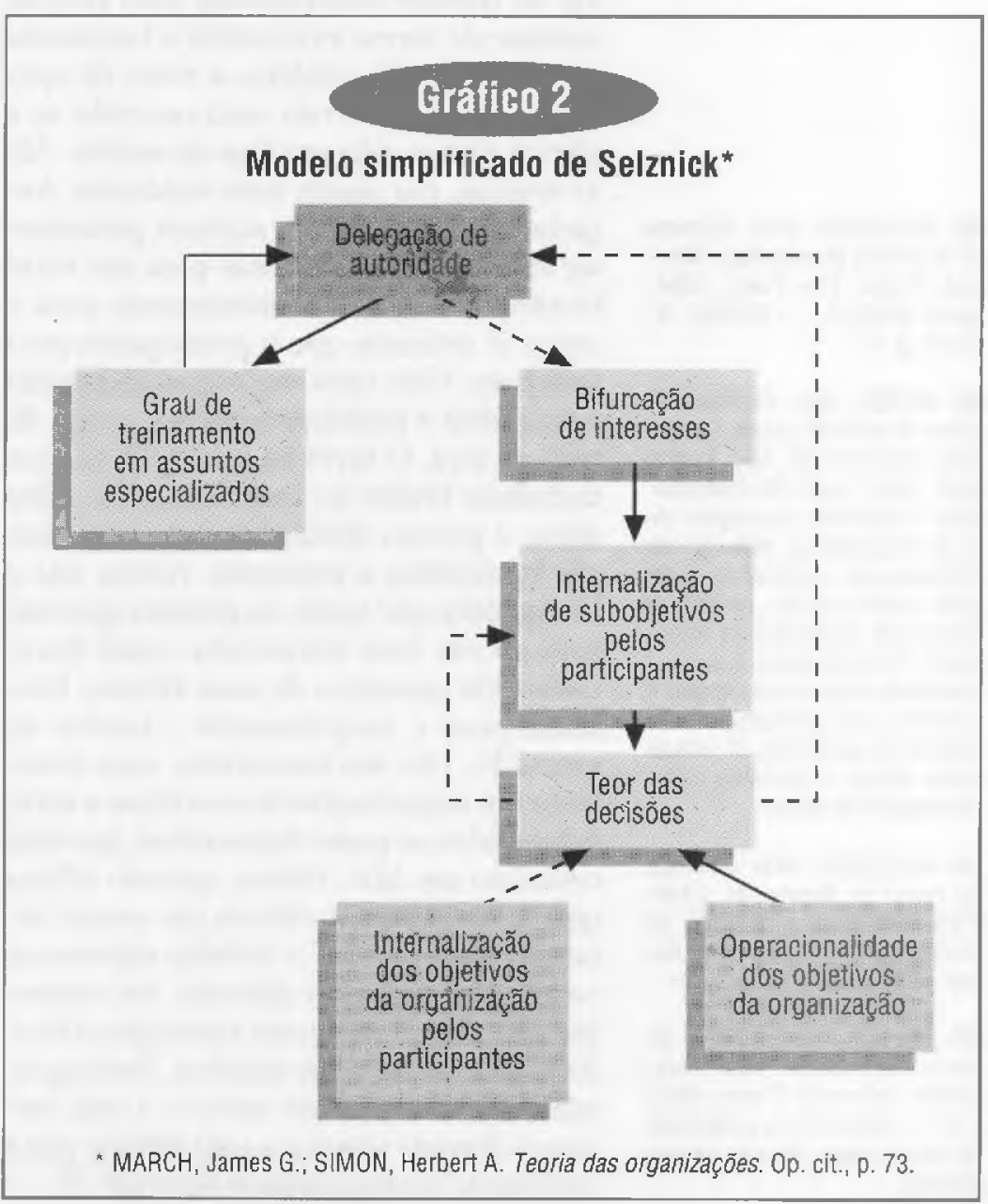


54. GOULDNER, Alvin. Patterns of Industrial Bureaucracy. Glencoe, Illinois: Free Press, 1954. Apud MARCH, J.; SIMON, H. Op.cit.,p. 57.

55. WEBER, Max. Parlamentarismo e governo numa Alemanha reconstruida. São Paulo: abril, 1974, p.23 (Os Pensadores). 0 chamado paradigma radical estruturalista, baseado em trabalhos de weberianos radicais (entre outros), permite o estudo de organizações como fonte de dominação. Uma das metáforas citadas por Morgan é o estudo das empresas como sistemas políticos, já citada neste artigo, e derivada desta abordagem de Weber.

56. GOULDNER, Alvin. Conflitos na teoria de Weber. In: CAMPOS, Edmundo. Sociologia da Burocracia. Rio de Janeiro: Zahar, 1966, p.61.

57. MILLS, C. W.; GERTH, H. From Max Weber. New York: Oxford University Press, 1946, p.254, original norte-americano de Weber, Max, Ensaios de Sociologia.
Para Gouldner, enquando unidade operacional, o grupo de trabalho tem sua sobrevivência altamente favorecida pelo estabelecimento de diretrizes gerais, $o$ que só estimula a adoção crescente de tais diretrizes. Ocorre, porém, que as normas de trabalho evocam, nos membros da organização, atitudes mais intensas do que aquelas pretendidas pelos detentores da autoridade, à medida que, definindo os padrões inaceitáveis de comportamento, estas normas burocráticas ampliam o conhecimento dos padrões mínimos aceitáveis. Se houver baixo nível de internalização dos objetivos da organização por parte dos funcionários, é de se esperar que a explicitação de níveis mínimos de desempenho admissíveis aumente a diferença entre o planejado e o realizado, dando margem ao que, vulgarmente, se dá o nome de nivelamento por baixo. ${ }^{54}$

O pressuposto é o da existência, na teoria de Weber, de conflitos decorrentes de uma eventual incapacidade do autor de ver as tensões burocráticas, pelo fato de analisar de forma primordial a burocracia governamental, solidária a nível de aparência. Tal deslize não teria ocorrido se a fábrica tivesse sido seu foco de análise. Ali, as tensões, por serem mais evidentes, forçá-lo-iam a ver que as normas poderiam ser racionais ou vantajosas para um nível hierárquico e não necessariamente para o outro. É evidente que o pressuposto peca pela base. Mais uma vez se pretende colar o tipo ideal à realidade e ver o que fica do lado de fora. O nível de abstração em que trabalhou Weber foi bem mais alto. Além disso, é preciso distinguir entre organização burocrática e burocrata. Assim, não é obrigatório que todas as pessoas que trabalham em uma burocracia sejam burocratas. Os operários de uma fábrica, limitados pura e simplesmente a tarefas de execução, não são burocratas, mas trabalham em organizações burocráticas e estão submetidos ao poder burocrático. Isso está cristalino em Max Weber, quando afirma que "é simplesmente ridículo que nossos literatos possam crer que o trabalho não-manual no escritório privado é diferente, um mínimo que seja, do trabalho numa repartição pública. Ambos são basicamente idênticos. Sociologicamente falando, o Estado moderno é uma 'empresa' (Betrieb) idêntica a uma fábrica: esta é exatamente sua peculiaridade histórica" ${ }^{55}$
Para Gouldner, há em Weber, além disso, uma "incipiente distinção entre normas impostas e normas estabelecidas por acordo, indicando dois aspectos mais amplos de um mesmo problema, entrelaçados em uma teoria". ${ }^{56}$ A afirmação acaba bem, mas começa muito mal: a distinção incipiente é nada mais, nada menos do que a visão clara da manifestação da dominação mediante poder de mando e subordinação, e da dominação mediante uma constelação de interesses - uma transformando-se facilmente na outra. Nada mais do que a base da teoria weberiana da burocracia, que nada tem de incipiente!

Tudo fica bem mais simples, quando se percebe a diferença entre "tipo ideal", "construção conceitual", e burocracia concreta e historicamente situada, refletindo as contradições fundamentais de uma dada formação social e contribuindo para acentuá-las. E é isto o que faz a burocracia sob o reino do antagonismo. $O$ que esperar de uma forma de dominação que tem a disciplina como aspecto fundamental, a qual, segundo o próprio Weber, tem como conteúdo "apenas a execução consistentemente racionalizada, metodicamente exercitada e exata da ordem recebida e na qual toda critica pessoal é incondicionalmente suspensa, cabendo ao ator única e exclusivamente executar a ordem" ${ }^{57}$

Em termos concretos, Gouldner também concebeu um modelo no qual a burocracia é vista como organização dotada de funções latentes e manifestas. A percepção de seu modelo é simples, a partir do gráfico 3 .

\section{MICHEL CROZIER}

Michel Crozier procurou fundamentar sua análise do sistema de organização burocrática na luta pelo poder e por sua manutenção. Todavia, não conseguiu, em suas primeiras e mais clássicas análises, fugir aos paradigmas da herança da crítica administrativa da burocracia já levantada. A crítica inicial de Crozier é um típico exemplo de como um método de análise pode empobrecer um conjunto rico de idéias.

Para ele, sensatamente, não se pode compreender o funcionamento de uma organização, sem levar em conta os problemas da administração os problemas 
da administração são vistos como problemas de ação cooperativa, muito mais do que como problemas de dominação. Por este motivo, tem como ponto de partida o pressuposto de que "toda ação cooperativa coordenada exige que cada participante possa contar com um grau suficiente de regularidade por parte dos outros participantes, ou seja, que toda organização qualquer que seja sua estrutura, quaisquer que sejam seus objetivos e sua importância, requer de seus membros uma quantidade variável, mas sempre importante, de conformidade". ${ }^{58}$

Até o início do século $X X$, a conformidade foi obtida por meio da violência, e as empresas do século XIX adotaram o velho modelo burocrático militar. Com toda razão, Crozier salienta que é um erro negligenciar, em sociologia histórica, a documentação disponível sobre os fundamentos das primeiras grandes organizações comerciais, dos primeiros exércitos permanentes e das ordens religiosas. ${ }^{59}$ Todavia, Crozier não faz uma sociologia histórica. Apresenta mais um modelo, dotado de quatro traços essenciais que caracterizam a burocracia moderna. Como os demais modelos já mencionados, peca pela falta de colocação da burocracia numa perspectiva histórica. ${ }^{60}$ Os quatro traços que Crozier apresenta, de forma crítica, são:

- a extensão do desenvolvimento das regras impessoais, que vê a burocracia como um freio ao arbítrio e ao favoritismo, mas, ao mesmo tempo, também a vê como um freio ao desenvolvimento da personalidade e da criatividade;

- a centralização de decisões, levando à rigidez organizacional;

- o isolamento dos níveis ou categorias hierárquicas, levando ao deslocamento de objetivos;

- o desenvolvimento de relações de poder paralelas.

O conjunto dessas quatro características tende a constituir uma série de círculos viciosos, reforçadores da impessoalidade e da centralização. Mais uma vez, a camisa de força do método funcionalista não permite perceber o real espírito da burocracia. Volta-se a um idealismo quase hegeliano, mas pobremente hegeliano; ressalte-se que a críti- ca do jovem Marx, desvendando a mistificação do interesse geral, é ignorada, e a leitura de Weber é feita fora da história. Afora isso, ao fazer uma crítica humanista da sociedade francesa, coloca a participação como um mito. ${ }^{61}$ Toda partjcipação será um mito? Há muitos exemplos históricos de participação. Se ela tende a ser uma forma de manipulação ou uma concessão secundária das elites dominantes, trata-se de um outro problema, que merece um estudo mais acurado. A solução é colocada na constituição de sistemas mais abertos de regulação, mediante o que se chama de investimento institucional, e tal investimento, "política e economicamente doloroso, começa por tornar os dirigentes políticos mais racionais". Assim, mudar-se-á a França e, talvez o mundo... A que outra conclusão se poderia chegar, a partir da outra constatação da burocracia como sistema incapaz da autocorreção? Para qualquer outra conclusão, seria necessá-

58. CROZIER, Michel. Le Phénomène Bureaucratique. Paris: Seuil, 1970, p.242.

59. CROZIER, Michel. Idem, ibidem, p. 243.

60. LAPASSADE, Georges. Grupos, organizaçóes a institui६̧ões. Rio de Janeiro: Francisco Alves, 1977, p. 145.

\section{CROZIER, Michel. Op.cit.}

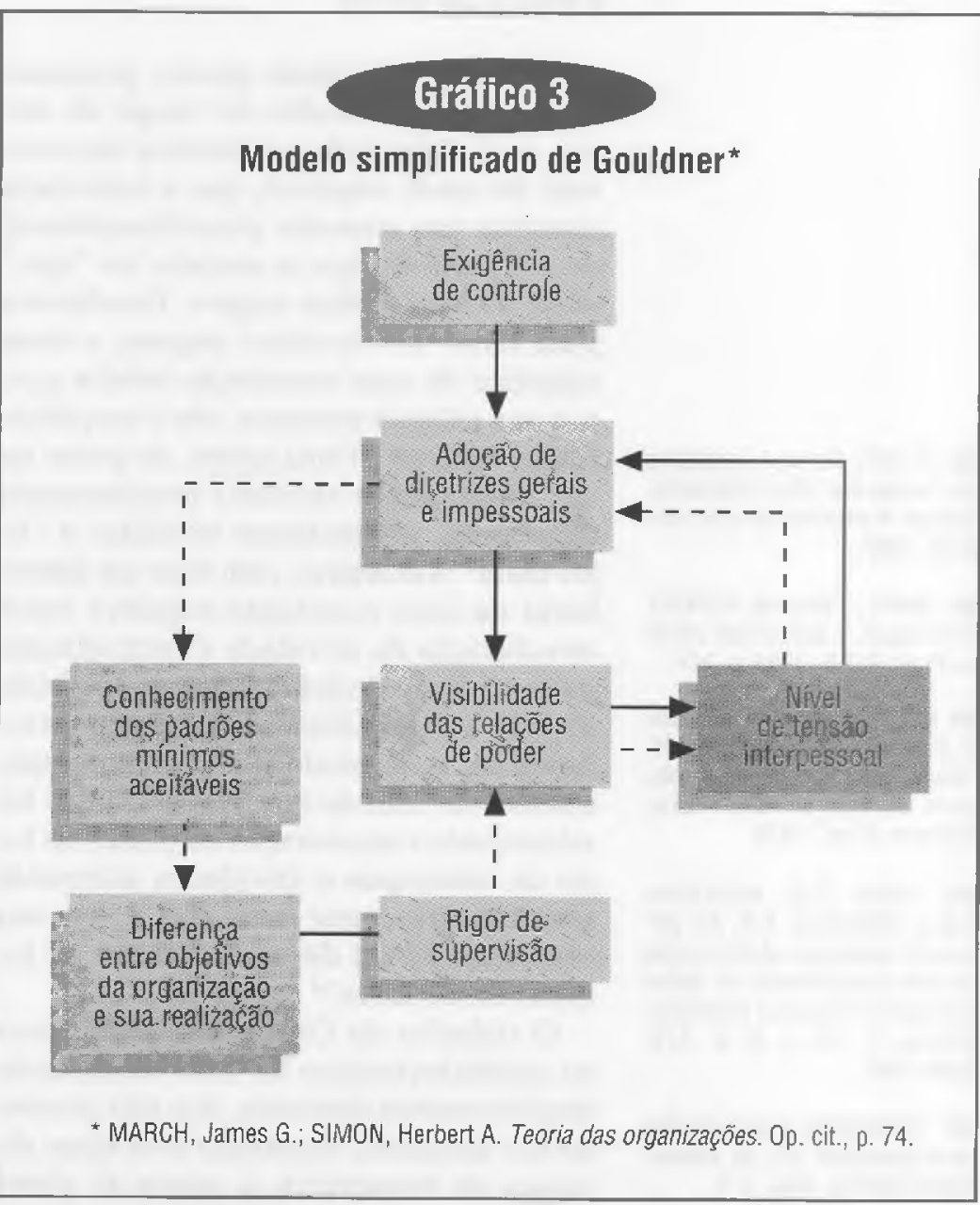


62. ALTER, Norbert. Logiques de l'entreprise informationnelle. Revue Française de Gestion. N.74, 1989.

63. MARC, Edmond; PICARD, Dominique. L'interaction socia/e. Paris: P.U.F., 1989, p. 114.

64. MOTTA, Fernando $C$. Prestes. 0 sistema e a contingência. In: Teoria geral da administração, uma introdução. São Paulo: Pioneira, $5^{\mathrm{a}}$ ed., 1976.

65. PUGH, D.S.; HICKDSN, D.S.J; HINNINGS, C.R. An empirical taxonomy of structures of work organizations. In: Administrative Science Quartely. Ithaca, v. 14, n. 3, p. 378 Sept.1969.

66. THOMPSON, Victor. Moderna organização. Rio de Janeiro: Freitas Bastos, 1967, p.5. rio que não se fizesse uma crítica burocrática da burocracia.

Com o atual desenvolvimento da gestão participativa de recursos humanos, os textos de Crozier, que dão ênfase à participação, são utilizados por alguns autores (principalmente interacionistas). Norbert Alter ${ }^{62}$, ao descrever as interações entre os diversos grupos da empresa informacional baseou-se em textos de Crozier. Edmond Marc e Dominique Picard fazem uma análise de Crozier aplicada a organizações, dentro do paradigma interacionista: "O conceito de ação estratégica desenvolvido por Crozier reforça a margem de liberdade que um ator social possui, não importando o contexto organizacional ao qual ele está submetido. $O$ ator não existe fora do sistema que define qual será sua liberdade e qual o tipo de racionalidade que ele poderá utilizar em sua ação, mas o sistema não existe sem o ator que o constitui e o forma, e que pode modificá-lo". ${ }^{63}$

\section{O GRUPO DE ASTON}

Em termos bastante gerais, podemos afirmar que o trabalho do Grupo de Aston, na Grã-Bretanha, pretendeu demonstrar, de modo empírico, que a burocracia constitui um conceito pluridimensional, ao contrário do que o conceito de "tipo" ideal de Max Weber sugere. Escolheram para tanto um caminho ingrato, o teste empírico de uma construção teórica que, por sua própria natureza, não é empiricamente testável. Ainda assim, de posse de um instrumento analítico relativamente sofisticado, pretenderam invalidar o "tipo ideal" weberiano, com base na descoberta de uma correlação negativa entre estruturação de atividade e centralização na tomada de decisões. Mesmo deixando de lado a ingenuidade da proposta metodológica, resta ainda um problema, que consiste no fato de que Weber parece ter relacionado concentração de poder no topo da hierarquia e atividades altamente estruturadas, o que nada tem a ver com centralização ou descentralização na tomada de decisões. ${ }^{64}$

O trabalho do Grupo de Aston levou ao estabelecimento de uma taxonomia empiricamente derivada, que não pretende ser exaustiva, incluindo sete tipos diversos de burocracia: a. plena; b. plena nascente; c. de fluxo de trabalho; d. nascente de fluxo de trabalho; e. de pré-fluxo de trabalho; f. burocracia de pessoal; $g$. organização implicitamente estruturada.

Estes tipos refletem o que o Grupo convencionou chamar três "dimensões" burocráticas, operacionalmente definidas: a. estruturação de atividade; b. concentração de autoridade; c. controle de linha de fluxo de trabalho. ${ }^{65}$ Além dos problemas que, já de início, comprometem sua pesquisa, o Grupo de Aston incorreu ainda em numerosos problemas de natureza conceitual, metodológica e operacional. Houve falha na definição das variáveis e chegou-se a resultados tautologicos, uma vez que formalização e padronização mediram quase a mesma coisa. Além disso, como foi amplamente reconhecido, existindo vinte empresas filiais em sua amostra, teria sido surpreendente encontrar baixa correlação entre centralização na tomada de decisões e perda de autonomia, e não o contrário, como concluíram os pesquisadores. $\mathrm{Na}$ verdade, $\mathrm{o}$ balanço do trabalho do Grupo de Aston aponta um empreendimento intelectual infeliz, apesar da grande divulgação que alcançou. De resto, todos os problemas encontrados na crítica administrativa da burocracia ali estão presentes.

\section{OUTROS CRÍTICOS E OS LIMITES DA CRÍTICA}

Há ainda muitos críticos que poderiam ser incluídos na vertente da crítica administrativa da burocracia. Entre eles estão, sem dúvida, W.W.White, Cris Argyris, Maslow, Warren Bynnis, McGregor, Presthus, Likert, Mouton e Blake e Herbert Shepard, que demonstram a obsolescência da organização burocrática, do ponto de vista das necessidades humanas. Alguns desses autores incidiram no engodo da organização pós-burocrática, outros não. Poucos, de qualquer forma, perceberam que o que importa é a análise da burocracia enquanto poder. Mesmo assim, chegaram a algumas colocações que são interessantes, como a de que a burocracia o leva a práticas e relações que, em larga medida, repetem a infância. ${ }^{66}$ Outras análises, estas sim mais interessantes, fogem aos paradigmas da crítica administrativa, colo- 
cando o estudo das organizaçōes em um nivel de indagação bem mais elevado; a crítica administrativa convencional da burocracia está, porém, há muito em crise, não se podendo esperar dela nenhum grande esclarecimento no que se refere à questão do controle social nas organizações. Ela prometeu muito e cumpriu pouco. A incapacidade de ver a burocracia como forma de poder historicamente situada está no centro dessa crise, que diz respeito não apenas à crítica administrativa, mas a toda a produção intelectual de cunho funcionalista. ${ }^{67}$

Aqui, porém, não é apenas a análise externa dessas colocações teóricas que revela a crise. São muitas vezes os próprios formuladores de crítica administrativa que chegam à percepção dos impasses que demonstram seus quadros de referência. Este é, por exemplo, o caso de Alvin Gouldner e Michel Crozier. Alguns trechos de obras suas mais recentes falam por si mesmos. Assim, afirma Gouldner: "Três forças contribuiram para a crise em pauta (do estrutural-funcionalismo): 1. o aparecimento de novas infra-estruturas, dissonantes em relação à teoria funcionalista estabelecida entre a juventude de classe média, estrategicamente intima do meio universitário em que a teoria social é feita e transmitida; 2 . os desenvolvimentos internos à própria escola funcionalista, que inseriram uma crescente variabilidade e hostilidade em seu trabalhouma entropia - e assim obscureceram a clare$z a$ e a assertividade de seus limites teóricos $e$ destruiram sua especificidade enquanto escoIa; 3. o desenvolvimento do welfare state, que aumentou consideravelmente os recursos disponíveis para a sociologia. Os funcionalistas acomodaram-se ao welfare state, mas, ao mesmo tempo, tal acomodação ocorreu através da geraçāo de tensöes que envolveram os pressupostos tradicionalmente centrais para o modelo funcionalista" ${ }^{68} \mathrm{Na}$ realidade, o funcionalismo sempre foi uma corrente legitimadora de uma formação social. Sua crise revela a fase mais profunda dessa formação. Basta pensar no que foi a década de 60 nos Estados Unidos e na França, por exemplo, para que isto se torne evidente.

Crozier e Friedberg são ainda mais claros na percepção da crise do quadro de referências que norteia a crítica administrativa da burocracia: "... toda estrutura de

ação coletiva se constitui como sistema de poder. Ela é fenômeno, efeito e fato de poder. Enquanto construção humana, ela organiza, regulariza, 'provisiona' e cria poder, para permitir aos homens a cooperação em empreendimentos coletivos. Toda análise séria da açāo coletiva deve, portanto, colocar o poder no centro de suas reflexões, pois, em última instância, a ação coletiva nada mais é do que a política cotidiana. O poder é sua matéria-prima. (...) Entretanto, o poder continua a ser o

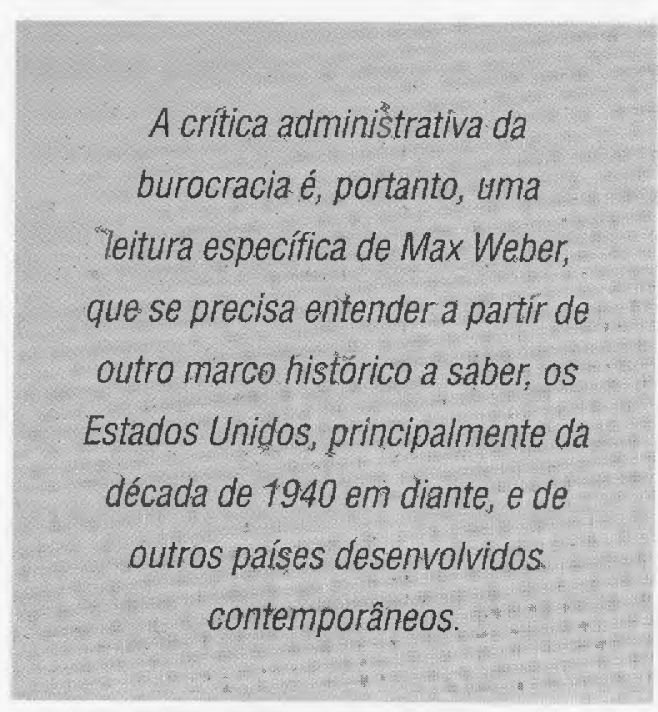

eterno ausente em nossas teorias da ação social. ${ }^{69}$ Naturalmente, quase tudo que se diz e se escreve sobre controle social nas organizações tem no poder o grande ausente. Também no que se diz a respeito da burocracia, forma de institucionalização da dominação, toda a atenção é concentrada nos arranjos administrativos e quase nenhuma na problemática do poder, o que torna a tradição managerialista bastante empobrecida em muitos aspectos. Fundamental é perceber o fenômeno do distanciamento que ocorre entre muitos teóricos organizacionais e as formulações de Weber, tido como seu inspirador.

\section{WEBER E A TRADIÇÃO MANAGERIALISTA}

A produção intelectual de Max Weber precisa ser compreendida a partir do marco histórico que a determina - a Alemanha do século XIX - e das primeiras décadas do século XX. A crítica administrativa da burocracia é, portanto, uma leitura específica de Max Weber, que se precisa entender a partir de outro marco his-
67. MOTTA, Fernando C. Prestes, Teoria das Organizações nos Estados Unidos e Uniāo Soviética. Revista de Administração de Empresas, Rio de Janeiro, FGV, v. 14, n. 2, 1974.

68. GOULDNER, Alvin. The coming crisis of Westarn sociology. New York/London: Basio Books, 1970 , p. 410

69. CROZIER, Michel; FRIEDBERG, Erhard. Lacteur et le système. Paris: Seuil, 1977, p.22-4. 
70. VERMEIL, Edmond. The German scene: social, political, cultural - 1890 to the present days. London: George Harrap, 1956. tórico a saber, os Estados Unidos, principalmente da década de $1940 \mathrm{em}$ diante, e de outros países desenvolvidos contemporâneos.

Assim, não se pode perder de vista que o Império Alemão, que desaparece realmente na época da eclosão da Primeira Grande Guerra, existiu durante um século sob as formas da Confederação Alemã, do autoritarismo bismarckiano e do reinado de Guilherme II. O período que vai de 1862 a 1866 tem especial relevância, já que nessa época a hegemonia prussiana sobre a austríaca torna-se um fato histórico e, em grande medida pelas mãos de Bismarck, a unificação alemã torna-se um problema resolvido.

Não fora resolvida, porém, a tensão com a França e as pressões exercidas por Napoleão III, que acabaram constituindo a base política da guerra franco-prussiana de 1870 a 1871 . Em resumo, os resultados dessa guerra foram a formação do Império Alemão, o II Reich sob Guilherme I, rei da Prússia e a perda, por parte da França, da Alsácia, salvo Belfort, e da maior parte da Lorena, bem como o pagamento de uma indenização de 5 bilhões de francos.

Se o equilíbrio do poder entre as potências européias garantiu um período relativamente tranqüilo para a Alemanha, tal equilíbrio durou somente até a Primeira Guerra Mundial. O país, no pré-guerra, tem uma ação política considerável, buscando a todo custo a aliança inglesa contra as investidas das potências continentais, além de procurar evitar um conflito armado nos balcões, onde fervilhava a rivalidade austro-russa. Talvez, porém, mais do que tudo, sua ação política se concentrasse na busca do isolamento da França, entre outras coisas, para que esta não reconquistasse a Alsácia e a Lorena.

De modo mais amplo, todo o período que compreende o século XIX e as primeiras décadas do século atual é de crucial importância política para a Alemanha. Bismarck foi um estadista forte, de ação decisiva. No plano da política externa, articulou todo um conjunto de alianças com a Rússia e a Áustria e posteriormente, com esta última e a Itália, institucionalizando a Tríplice Aliança em 1882. A política externa, de Bis- marck, tanto quanto a interna, foi inclusive responsável por sua demissão em 1890, a partir de desacordos manifestos com Guilherme II. O que o primeiro temia por ocorrer: a Tríplice Entente, entre Grã-Bretanha, Rússia e França. A Tríplice Entente surge como uma frente, em face da Tríplice Aliança da qual a Alemanha fazia parte. Esta é a situação às vésperas da Primeira Guerra Mundial. A Alemanha é palco de uma situação interna na qual a hegemonia do Estado sobre a sociedade civil é incontestável. A situação econômica é de instabilidade, e a social e política, de crise e fraqueza. A elite burocrática estatal é forte, à medida que a burguesia e o proletariado não conseguem se impor nem juntos, nem isoladamente. O Parlamento não tinha qualquer poder efetivo sobre a burocracia, o que equivale a dizer que esta absolutamente não era controlada de forma adequada aos padrões de uma democracia liberal.

No plano econômico, a Alemanha não consegue trocar seus produtos em posição competitiva, devido à Tríplice Entente. No plano social, o clima é de temor. As classes médias obtêm pouco proveito de uma economia dominada por trustes e cartéis. Os grandes proprietários temem os perigos que vêm do exterior, o proletariado procura se proteger no Partido Social Democrata e nos sindicatos. Os pequenos burgueses temem as reivindicações trabalhistas. $\mathrm{O}$ Parlamento, sem poder efetivo, está muito longe de poder ser visto como representante real do povo. O delírio coletivo exacerbado do pan-germanismo é dominante no começo do século. ${ }^{70}$

Nesse contexto, Weber estuda a burocracia, e sua erudição o leva à elaboração de uma sociologia, nem positivista, nem marxista, onde a teorização sobre a dominação constitui elemento central. A obra monumental de Weber não recusa as determinações históricas. Ao contrário, as instituições administrativas são estudadas em épocas muito diversas, e o estudo da racionalidade burocrática, que lhe é contemporânea, é paralelo ao da racionalidade capitalista. $\mathrm{Na}$ Alemanha, onde Weber produz teoricamente, ele é um profeta desarmado. Percebe o poder da burocracia e percebe o seu perigo. No 
plano político, propugna seu controle pelo Parlamento.

Todavia, a teorização de Weber foi por demais empobrecida pela reinterpretação cultural feita pela teoria administrativa. Todo o esforço foi dirigido no sentido de concentrar a atenção no "tipo ideal" de organização burocrática, de perceber se as organizações se adaptavam a ele ou não. Com isto, perde-se de vista a problemática central, ou seja, a dominação burocrática. Assim, a crítica administrativa, ao afirmar que estamos passando para uma fase de organizações pós-burocráticas, na verdade legitima ideologicamente a burocracia enquanto poder e dominação que é. Por esta razão é preciso enfatizar o que é mais rico na sociologia política de Weber: a teoria da dominação.

Max Weber preocupa-se com a forma pela qual uma comunidade social aparentemente amorfa chega a se transformar em uma sociedade dotada de racionalidade. Tal passagem dar-se-ia por meio do que chama de ação comunitária, cujo aspecto fundamental é a dominação. Esta pode manifestar-se como dominação mediante uma constelação de interesses, ou como dominação em função do poder de mando e subordinação. De qualquer forma, porém, uma pode facilmente transformar-se na outra.

A dominação deve ser entendida como um estado de coisas no qual as ações dos dominados aparecem como se estes houvesse adotado como seu o conteúdo da vontade manifesta do dominante. Assim, embora a dominação seja uma forma de poder, ela não é idêntica ao poder. Poder é a possibilidade que alguém ou algum grupo tem de realizar sua vontade, inclusive quando esta vai contra a dos demais agentes da ação comunitária.

A manifestação de qualquer dominação dá-se sob a forma de governo. ${ }^{71}$ Isto ocorre porque as tarefas a serem realizadas exigem um aumento crescente de treinamento e experiência. Assim, a necessidade técnica favorece a continuidade dos funcionários, levando ao que Weber chama de dominação mediante organização. A dominação organizada confere uma vantagem aos funcionários, em face da massa dominada. ${ }^{72}$ Tal vantagem decorre de seu número relativamente pequeno, que possibilita o acordo rápido no sentido da conservação de suas posições, na criação e direção de uma ação racional. Embora tal vantagem se vá tornando menos provável à medida que aumenta o número de funcionários, as disposições que regem a socialização garantem aos chefes terem à sua disposição, de modo constante, um círculo de pessoas interessadas em participar no mando e em suas vantagens.

O círculo de funcionários potenciais, próximos aos chefes, permite o exercício do poder de coação e a manutenção da dominação, configurando aquilo que Weber chama de estrutura de uma forma de dominação: o relacionamento entre o chefe e seu aparato administrativo, e entre ambos e os dominados. Esta estrutura aparecerá nas diversas formas que pode assumir a dominação, fundamentalmente tradicional, racional-legal e carismática. Tais tipos constituem uma resposta à questão da legitimidade da dominação, isto é, dos princípios em que se apóia a exigência de obediência dos funcionários ao senhor, e dos dominados a ambos.

Como sabemos, a dominação legal fundamenta-se no primado da regra racional estabelecida, manifestando-se em sua forma mais pura na burocracia, tipo específico de sua estrutura. É sempre bom lembrar que Weber tratou a burocracia como "tipo ideal", ou seja, como uma construção conceitual a partir de certos elementos empíricos que se agrupam, logicamente, em uma forma precisa e consistente, mas que, em sua pureza, nunca se encontram na realidade. ${ }^{73} \mathrm{De}$ qualquer modo, porém, o formalismo, a impessoalidade e o profissionalismo burocrático traduzem-se em uma administração heterônoma, onde a autoridade flui de cima para baixo, assumindo uma forma piramidal, e evidenciando seu caráter monocrático, isto é, a obediência ao princípio da unidade de comando.

A heteronomia burocrática significa a ausência de qualquer autonomia individual ou social, no que diz respeito à participação no processo administrativo. A ação individual está claramente limitada pelas posições na pirâmide organizacional. Que não restem dúvidas, para Weber, "a burocracia é um tipo de poder. Burocracia é igual a organização. É um sistema em que a divisão de trabalho se dá racionalmente,
71. WEBER, Max, Economia $Y$ sociedad. México: Fondo de Cultura Económica, 1974, v.2, p. 701.

72. WEBER,Max. Idem, ibidem, p. 704 .

73. WEBER, Max. On the methodology of the social sciences. Illinois: Glecoe, 1949, p. 90-3. 
74. TRAGTENBERG, Maurício. Burocracia e Ideologia. São Paulo: Ática, 1974, p.139.

75. MOUZELIS, Nicos. Organization and Bureaucracy. New York: London School of Economics, Aldine-Atherton, 1972 , p.20 (tese de doutoramento).

76. WEBER, Max. Parlamentarismo e Governo. Op.cit.

77. BENNIS, Warren. Organizacões em mudanca. São Paulo: Atlas, 1976, p. 18; PERRY, Marvin. Civilização ocidental - uma história concisa. São Paulo: Martins Fontes, 1985, p. 623.

78. KURZ, Robert. $O$ colapso da modernização: da derrocada o socialismo de caserna à crise da economia mundial. Rio de Janeiro: Paz e Terra, 1992, 244 p. visando a determinados fins. $A$ ação racional burocrática é a coerência da relação de meios $e$ fins visados." 74

Toda a teorização weberiana está inserida em uma filosofia da história que revela um certo grau de pessimismo que outros grandes pensadores sociais não compartilham. Essa filosofia, traduzida em termos simples, implica a tensão entre o carisma, representando as forças criativas e espontâneas da sociedade, e a rotina. "No processo histórico, o líder carismático constitui uma força revolucionária. Nos momentos críticos, quando as instituições sociais se tornam rigidas demais e inadequadas para enfrentar situações dificeis e novas, o carisma, uma força destruidora, derruba a ordem estabelecida e abre novos caminhos de vida. Mas a vitória do carisma sobre a rotina nunca é definitiva Ao contrário, o carisma acaba sendo rotinizado, estabelecendo novamente a ordem das coisas. "75

Para Weber, a burocracia não do mundo moderno constituía a maior ameaça à liberdade individual e às instituições democráticas das sociedades ocidentais. A burocracia, era, portanto, um perigo, e, por esta razão, devia ser sempre controlada pelo Parlamento. ${ }^{76}$

Entretanto, mesmo assim, ele via o político adotando cada vez mais a ética do burocrata, com a burocratização dos partidos políticos. O pessimismo weberiano, longe de ser para nós motivo de desilusão, deve ser um alerta. Mais do que isto, deve-se perceber nele o seu desagrado para com a burocracia. Referindo-se a um debate no qual Weber tomou parte, Warren Bennis faz uma tradução aparentemente um pouco livre, das palavras de Weber, mas que, de qualquer forma, dá uma idéia bastante forte de suas preocupações neste sentido: "É horrivel pensar que o mundo possa vir a ser um dia dominado por nada mais que homenzinhos colados a pequenos cargos, lutando por outros maiores; situação que será vista dominando parte sempre crescente do espírito do nosso sistema administrativo atual e, especialmente, de seu produto: os estudantes (...) A paixão pela burocracia é suficiente para levar alguém ao desespero. $O$ mundo só conhece homens como estes - é esta a situação a que já chegamos e a grande pergunta não é, portanto, como podemos promovê-la e apressá-la, mas o que opor a esse mecanismo para conservar uma parte da humanidade livre dessa fragmentação da alma, desse domínio supremo do modo burocrático de vida." 77

Coloca-se, assim, uma discussão teórica fundamental para a questão do poder e do controle social nas organizações, da qual podem ser deduzidas muitas outras hipóteses para pesquisa teórica e empírica.

O autor termina seu artigo aqui, mostrando como a racionalidade burocrática levada ao excesso pode ser prejudicial.

\section{CONCLUSÃO}

Logo no início do presente trabalho viu-se como a questão do controle social é central na análise organizacional, por sua característica de instância de controle a serviço de sistemas sociais maiores. Hoje pode-se afirmar que esta temática é central não só do ponto de vista teórico, como também para a compreensão das alternativas que se colocam para um universo organizacional e social acelerado processo de mudança.

A lógica de produção capitalista obriga o desenvolvimento das forças produtivas. A competição econômica força as organizações a buscarem uma performance superior, renovando permanentemente o trabalho, a técnica e os produtos, e dando origem a um espiral de mudanças infinito e vertiginoso.

Um ponto crucial deste desenvolvimento ocorre após a Segunda Guerra Mundial, no casamento, em condições de mercado globalizado, da investigação científica com o processo produtivo. A partir daí, a distância econômica entre os blocos políticos se acentua. Os países socialistas e do terceiro mundo não conseguem seguir os passos dos países desenvolvidos.

O filósofo alemão Robert $\mathrm{Kurz}^{78} \mathrm{de}$ senvolveu uma teoria para o momento atual. Para Kurz, o mundo todo está integrado num único sistema, de forma que uma crise nos países periféricos implica problemas nos países centrais. Além disso, a concorrência no mercado mundial torna obrigatório o novo padrão de produtividade, que combina necessidade de uma grande infra-estrutura com alta tecnologia e vultosos investi- 
mentos. Este novo padrão, num mercado altamente interligado, representa um limite no processo de desenvolvimento capitalista. Pela primeira vez, o aumento de produtividade implica dispensa de trabalhadores, restringindo o mercado consumidor.

A globalização econômica tem implicações antes impensáveis. A vitória de uma empresa não significa apenas a derrota de sua concorrente, mas, eventualmente, pode acarretar impactos sociais graves a comunidades inteiras do outro lado do mundo. Os países do terceiro mundo, perdidos no meio de uma transição incompleta ao industrialismo, debatem-se em crises internas e não conseguem formular projetos nacionais capazes de superar os impasses.

Paralelamente às macromudanças, as organizações refletem e catalizam novas mudanças. A aceitação da visão mecanicista, da organização de comando e controle, da burocracia de inspiração weberiana, coincide com a ascensão da civilização urbano-industrial. Seu declínio, por sua vez, leva a um questionamento das limitações do modelo tradicional.

O modelo tradicional enfatizava equilíbrio e estabilidade. Relacionava-se, portanto, a sistemas sociais fechados. Com a transição para uma sociedade baseada em grandes movimentações de capital, tecnologia e trabalho, no qual inovação é um valor central e informação um recurso fundamental, o modelo tornou-se superado.

A "ascensão" da dimensāo simbólicocultural à categoria de objeto de interesse dos estudiosos das organizações parece refletir uma duplicidade de ponto de vista sobre a realidade da reforma das organizaçōes burocráticas.

De um lado, pode-se entender a incorporação desta dimensão dentro do processo de renovação das burocracias como analisado sob a lente do "pessimismo" weberiano. De fato, os movimentos atuais de reorganização do trabalho, especialmente sob a palavra de ordem da qualidade, são significativos de um certo "neofuncionalismo", que busca introduzir novas formas de dominação e controle social através da manipulação criativa de símbolos, ritos e outros elementos culturais.
De outro lado, pode-se assumir uma postura mais próxima dos radicais-humanistas, seguindo, por exemplo, a trilha proposta por Durand 79 . Para o autor, a nossa sociedade cientificista, positivista e iconoclasta confundiu desmistificação com desmitificação. Mas esta mesma sociedade criou um "museu imaginário" através dos meios de informação e comunicação, que pošsibilita uma confrontação de culturas em escala mundial e

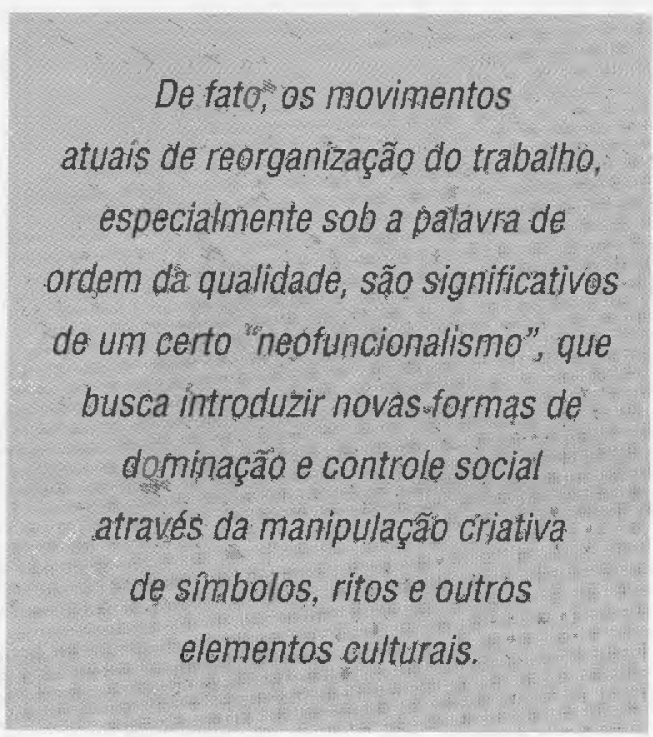

propicia um reequilíbrio remitificador em escala planetária. Desta forma, a incorporação da dimensão simbólico-cultural poderia estar relacionada com o avanço de um processo criativo de individuação, capaz de catalisar profundas mudanças nas organizaçōes.

Mas, qualquer que seja a postura assumida, não parece haver dúvidas sobre as potencialidades contidas na adoção da dimensão simbólico-cultural como ferramenta analítica para o estudo dos sistemas de controle e das configuraçóes de poder nas organizações. Parecem extremamente fecundas as possibilidades geradas com a incorporação destes conceitos à herança analítica weberiana, base estrutural obrigatória de qualquer análise das organizações burocráticas.

Neste sentido, uma "leitura simbólica" da obra de Weber pode vir a tornar-se um recurso poderoso para o estudo das organizações pós-industriais e, especificamente, dos processos de mudança atuais. $\square$
79. DURAND, Gilbert. Op. cit., p. 105. 